\title{
Treatment of allergic asthma: Modulation of Th2 cells and their responses
}

\author{
Berislav Bosnjak, Barbara Stelzmueller ${ }^{1}$, Klaus J Erb² $^{2}$ and Michelle M Epstein ${ }^{1 *}$
}

\begin{abstract}
Atopic asthma is a chronic inflammatory pulmonary disease characterised by recurrent episodes of wheezy, laboured breathing with an underlying Th2 cell-mediated inflammatory response in the airways. It is currently treated and, more or less, controlled depending on severity, with bronchodilators e.g. long-acting beta agonists and long-acting muscarinic antagonists or anti-inflammatory drugs such as corticosteroids (inhaled or oral), leukotriene modifiers, theophyline and anti-lgE therapy. Unfortunately, none of these treatments are curative and some asthmatic patients do not respond to intense anti-inflammatory therapies. Additionally, the use of long-term oral steroids has many undesired side effects. For this reason, novel and more effective drugs are needed. In this review, we focus on the CD4+ Th2 cells and their products as targets for the development of new drugs to add to the current armamentarium as adjuncts or as potential stand-alone treatments for allergic asthma. We argue that in early disease, the reduction or elimination of allergen-specific Th2 cells will reduce the consequences of repeated allergic inflammatory responses such as lung remodelling without causing generalised immunosuppression.
\end{abstract}

\section{Introduction}

Asthma is a serious chronic inflammatory lung disease characterised by recurrent episodes of wheezy laboured breathing with prolonged expiration accompanied by dry coughing and viscous mucus. These symptoms result from bronchoconstriction, bronchial mucosal thickening by oedema, eosinophilic infiltration, bronchial wall remodelling and excessive mucus production with plugging of the conducting airways in the lungs. These airway changes lead to increased bronchial hyperreactivity to a variety of allergic and non-allergic stimuli. Obstruction is usually reversible, either spontaneously or in response to appropriate therapy. Asthma affects approximately 300 million people worldwide and can be fatal. Atopic or allergic asthma generally occurs in childhood or young adulthood (under the age of 40) in about $70-80 \%$ of cases and is caused by common allergens e.g. pollens, house dust, animal dander, inhalants, foods, drugs and occupationally encountered dust. Atopic asthma is characterised by detectable allergen-specific $\operatorname{IgE}$ and a positive skin test upon allergen provocation. The most severe chronic refractory asthma accounts for

\footnotetext{
* Correspondence: Michelle.Epstein@meduniwien.ac.at 'Department of Dermatology, DIAID, Experimental Allergy Laboratory, Medical University of Vienna, Vienna, Austria Full list of author information is available at the end of the article
}

$5-10 \%$ of adults with asthma and is characterised by persistent symptoms and frequent exacerbations, despite treatment with high dose inhaled and/or oral corticosteroids and inhaled $\beta 2$ adrenoceptor agonists. These patients are at greater risk of fatal and near-fatal exacerbations and display serious unremitting symptoms, resulting in a considerable impact on quality of life, disproportionate use of health care resources and adverse effects from regular systemic steroid use.

The allergic immune response is a complex process beginning with the activation of allergen-specific Th2 cells by antigen presenting cells (APCs) followed by their proliferation, cytokine production, helper functions and the emergence of memory cells (Figure 1). The resulting pathophysiological response includes lung eosinophilic inflammation, oedema, smooth muscle contraction and increased mucus production, resulting in airway obstruction and eventual lung damage. Numerous experimental models and clinical studies support a central role of allergen-specific Th2 cells in pathophysiological responses [1-4]. Although much is known about the pathogenesis of the disease, the mechanisms underlying Th2 cell differentiation and perpetuation remain unclear. Allergen-specific memory Th2 cells take up long-term residence within experimental mice after recovering from a single episode allergic asthma [5] 


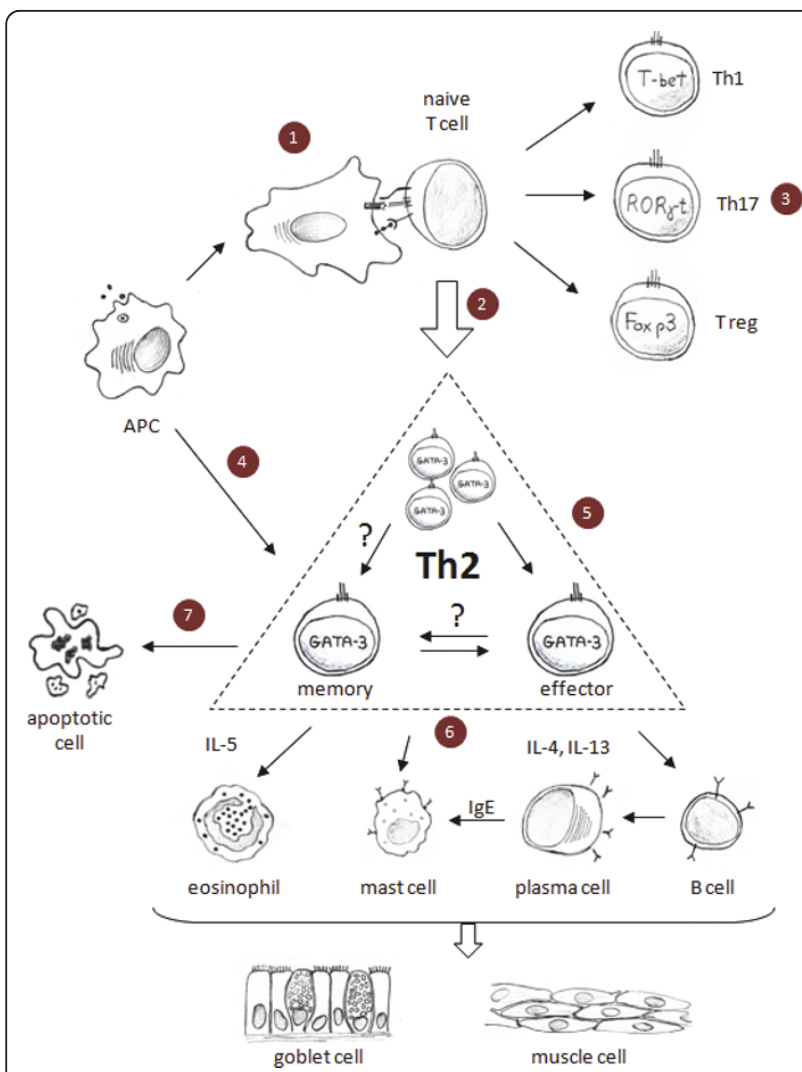

Figure 1 Helper Th2 cells play a central role in allergic asthma and could be targeted through individual allergic immune processes. (1) Allergen handling and presentation by activated APC to naive CD4+ T cells induces their activation. (2) Activated naïve CD4+ T cells differentiate to Th2 cells, or (3) possibly to other types of helper T cells e.g. Th1, Th17 or Treg cells. (4) Secondary exposure to allergen leads to Th2 cell activation, (5) as well as their migration into the lungs. (6) Activated Th2 cell-mediated asthma is caused in part by the secretion of interleukins e.g. IL-4, IL-5 and IL-13. These cytokines stimulate B cell activation and IgE secretion. Th2 cell cytokines and IgE activate cells of the innate immune system e.g. eosinophils, mast cells, etc. causing the release of vasoactive, proinflammatory mediators, smooth muscle contraction, mucus hypersecretion, oedema and, eventually, airway remodelling. (7) Homeostasis and survival of memory $T$ cells in the lymph nodes and lungs perpetuates disease. Interruption of these molecular and cellular targets may reduce symptoms and pathological consequences of allergic asthma.

illustrated by the maintenance of elevated serum allergen-specific IgG1 and persistent inflammatory chronic lung infiltrates. Asthma exacerbations are induced by respiratory tract allergen challenge leading to pathology resembling patients [6-8]. A reduction or elimination of specific Th2 responses permits the treatment of disease without causing generalised immunosuppression and makes it a prime target for disease abrogation. Although current asthma therapies (especially inhaled corticosteroids and $\beta 2$-agonists) efficiently control the disease, development of novel drugs is crucial for disease control in patients with severe, corticosteroid-insensitive asthma, as well as for improvement of existing therapies in terms of a more favourable side effect profile [9]. Additionally, the use of highly active drugs that reduce disease in the early stages may obviate the need for high dose steroids later on and may reduce the potential for unremitting, steroid-resistant disease. Current asthma therapies do not cure the disease and symptoms return soon after treatment is terminated. Treatment in the late stages of chronic, severe, unremitting allergic asthma may be too late. It is therefore, important to start treatment early to reduce disease. In the early stages of disease, allergen-specific Th2 memory cells appear to play an important role in initiating the immune response against the offending allergen. Eliminating these pathogenic cells at an early stage may lead to complete disease remission. There is a myriad of strategies to eliminate Th2 memory cells that are promising. This review focuses on these targets during the evolution of the Th2-mediated allergic immune response from allergen presentation to activation and survival of Th2 memory cells (Figure 1).

\section{Improvement of existing anti-Th2 cell therapies}

Inhaled and oral corticosteroids, leukotriene modifiers, theophyline, anti-IgE and specific allergen immunotherapy (AI) are well-established treatments for asthma [10]. Of these therapies, only AI specifically targets Th2 cells [11]. AI is thought to function by either skewing the allergic Th2 response towards Th1 immunity or generating regulatory $\mathrm{T}$ cells (Tregs) $[12,13]$. While the mechanism remains controversial, AI is effective in a subset of patients. Classical immunotherapy or "allergy shots" in the last years is evolving towards non-injectable forms like subcutaneous and sublingual immunotherapy $[13,14]$. Progress in AI focuses on the dose and nature of the allergens, with higher allergen doses improving AI effectiveness [15] and chemically modified allergens (allergoids) increasing efficacy $[14,16]$. The production of recombinant allergens of common allergens from DNA sequences that can be mutated, fragmented or chimerised leads to efficient hypoallergenic mixtures of allergens for treatment $[14,17,18]$. Additionally important is the ability of producing $\mathrm{T}$ cell epitopes without $\mathrm{B}$ cell epitopes, which reduces adverse reactions $[12,16,17]$ or new technologies like covalently linked $T$ cell epitopes [14], DNA vaccines encoding allergens [19], production of fusion proteins to increase allergen presentation [20], or expression of recombinant allergens in lactic bacteria able to colonise the gut [21]. Equally promising is the production of random peptide libraries to determine structural equivalents, so called mimotopes [14], producing shorter peptides [16,22], though patients may develop de novo IgE antibodies 
against the treatment peptide. Although some novel adjuvants such as monophosphoryl lipid A from Salmonella minnesota $[12,23]$ or heat killed or live Mycobacterium tuberculosis did not meet expectations in clinical trials [14], other adjuvants like fusion proteins with bacterial surface layer components [14] and cytosine-guanine dinucleotides ( $\mathrm{CpG}$ ) oligonucleotides (CpG-ODNs) $[9,12,23]$, as well as routes of allergen delivery, in oral microencapsulated forms [24] or embedded in nanoparticles [23], are being explored.

\section{Strategies to modulate antigen presentation and Th2 cell activation}

Dendritic cells (DCs) expressing CD11 ${ }^{+} \mathrm{CD} 11 \mathrm{~b}^{+}[25]$, $\mathrm{CD}^{+} 6^{+}$[26], CD141 ${ }^{+}$[27] or CD8 $\alpha$ [28] predispose to allergic asthma. Sputum and bronchial biopsies of asthmatic patients contain higher DC numbers in comparison to healthy individuals $[29,30]$ and are increased after allergen exposure [31]. Asthmatic DCs differ in cytokine, prostaglandin (PG), and chemokine synthesis and costimulatory molecule expression compared to healthy controls [32-34]. In addition, allergen-pulsed DCs from asthmatic patients, but not healthy controls, preferentially stimulate T- cells to produce IL-4 [35]. DCs from asthmatics produce high amounts of PGE2 [34], which decreases IL-12 [36] and increases CCL17 and CCL22 production [37] from DCs causing the polarisation of DCs, which promote Th2 cell differentiation and recruitment. Recently, thymic stromal lymphopoietin (TSLP) has emerged as a key mediator, which promotes DC-induced Th2 differentiation through the interaction of OX40:OX40L $[38,39]$. Inhibition of DC-mediated antigen presentation represents a suitable treatment option for allergic diseases. While DCs are the most potent APCs, other cells also contribute to antigen presentation and may provide useful targets. Table 1 illustrates the cell type, target and mechanism of action for compounds and biologicals that reduce antigen presentation to Th2 cells and their subsequent activation.

\section{Interference with Th2 differentiation and activation}

Antigen presentation induces clonal expansion and differentiation of naïve Th cells into mature Th1, Th2, Th17 or inducible Tregs [reviewed in [40]]. Th2 cell polarisation is mediated by transcription factors, including GATA-3, which are crucial for Th2 lineage commitment. Initial signals that drive Th2 differentiation induce expression of the GATA-3 [41], which mediates Th2 differentiation by inducing chromatin remodelling of Th2 gene loci, direct transactivation of Th2 gene expression and inhibition of IFN $\gamma$ expression [42]. Furthermore, GATA-3 expression must be sustained to maintain a Th2 phenotype $[42,43]$. Beside other important factors, microRNAs have recently emerged as regulators of gene expression during differentiation and function [reviewed in $[44,45]]$. Numerous microRNAs play important roles in asthma [46] and selective inhibition of these molecules can be utilised to specifically target development of Th2 cells. Examples of other signal transduction pathway targets and their inhibitors are listed in Tables 2 and 3. Unfortunately, most of these targets are not selectively expressed in Th2 cells and their inhibitors have broad immunosuppressive effects.

\section{Modulation of effector cytokines}

The interplay between cells and cytokines involved in Th2-mediated disease is complex. Th2 cells secrete and express a variety of cytokines and receptors [40]. In the past decade, mAbs targeting the most prominent Th2 cytokines, IL-4, IL-5 and IL-13 have had variable success in clinical trials and the perception is that effectiveness will be improved by inhibiting two or all of them simultaneously. Furthermore, additional cytokines including IL-9 and IL-31 are secreted by Th2 cells and might represent novel or additive targets. Moreover, cytokines secreted by other cells such as Th1, Th17 and Tregs may suppress Th2 cell function. Importantly, augmenting suppressive effects and inhibiting disease-promoting effects of $\mathrm{T}$ cells may lead to new compounds. Table 4 illustrates examples of cytokines secreted by Th2 cells, have direct effects on Th2 differentiation or are involved in differentiation of other helper $\mathrm{T}$ cell subtypes that could inhibit Th2 cells.

\section{Interference of Th2 cell homing and adhesion}

Chemokine-chemokine receptors (CKRs) are a complex system of 42 molecules and 19 receptors that orchestrate leukocyte migration in physiologic and pathologic conditions [47]. Among CKRs, CCR4, CCR8, CXCR4 and CCR3 appear to be selectively expressed on Th2 lymphocytes $[48,49]$ making them potentially important specific Th2 cell targets. CCR4 regulates chemotaxis of Th2 cells and its ligands CCL17 and CCL22 are elevated in allergic asthma [50,51]. Hence, selective CCR4 antagonists, such as bipiperidinyl carboxylic acid amides, or antibodies directed against CCR4 ligands could be promising treatments $[9,50,51]$. However, CCR4 is also expressed on Tregs and cells with either Th1 or Th2 potential [52] leading to CCR4 inhibitors causing immunosuppressive effects. CCR8 expression also appears to be increased in lung and airway Th2 cells in asthmatic patients [53]. Airway eosinophilia and airway hyperresponsiveness (AHR), however, are not diminished in $\mathrm{CCR}^{-1-}$ mice [54] and adoptively transferred Th2 cells not expressing CCR8 accumulate in the lungs [55]. Despite these contrasting results, several CCR8 agonists [56] and antagonists [57] are in development and might help to clarify the role of CCR8 in disease pathogenesis. 
Table 1 Antigen presenting cell targets

\begin{tabular}{|c|c|c|c|c|}
\hline Cell type & Target & Intervention example & Mechanism of action and effects & Comments \\
\hline \multirow[t]{7}{*}{$\begin{array}{l}\text { Dendritic } \\
\text { cell }\end{array}$} & $\begin{array}{l}\text { Peroxisome } \\
\text { proliferator- } \\
\text { activated } \\
\text { receptor } \\
\text { gamma }\end{array}$ & Rosiglitazone and ciglitazone & $\begin{array}{l}\text { Decrease CCR7 expression on DCs and } \\
\text { diminishes migration }[144,145]\end{array}$ & - \\
\hline & $\begin{array}{l}\text { Sphingosine 1- } \\
\text { phosphate } \\
\text { inhibitor }\end{array}$ & FTY720 & $\begin{array}{l}\text { Sequesters lymphocytes in secondary } \\
\text { lymphoid organs; inhibits T cell } \\
\text { migration to the draining lymph nodes } \\
\text { [146-;] suppresses eosinophilic airway } \\
\text { inflammation and AHR, reduced Th2 cell } \\
\text { generation [147,148], generalised } \\
\text { immunosuppression [149] }\end{array}$ & $\begin{array}{l}\text { In clinical study for moderate asthma } \\
\text { (ClinicalTrials.gov identifier: } \\
\text { NCT00785083) }\end{array}$ \\
\hline & $\begin{array}{l}\text { Thymic stromal } \\
\text { lymphopoietin } \\
\text { (TSLP) }\end{array}$ & Anti-TSLP antibodies [39] & $\begin{array}{l}\text { TSLP skews DCs to express high levels of } \\
\text { OX40 ligand, which promotes the } \\
\text { generation of Th2 cells [38]; its inhibition } \\
\text { prevents Th2-mediated airway } \\
\text { inflammation in mice [39] }\end{array}$ & - \\
\hline & CCL2 & CCR2 antagonists [150] & $\begin{array}{l}\text { Overexpressed in lung and increased DC } \\
\text { recruitment in allergic asthma }[151,152]\end{array}$ & $\begin{array}{l}\text { CCR2 is involved in migration of other } \\
\text { immune cells as well }\end{array}$ \\
\hline & $\begin{array}{l}\text { CD80/86 } \\
\text { costimulation }\end{array}$ & $\begin{array}{l}\text { D prostanoid } 1 \text { receptor } \\
\text { agonist [153], aerosolised CD86 } \\
\text { antisense oligonucleotide [154] } \\
\text { or suplatast tosilate [155], }\end{array}$ & $\begin{array}{l}\text { Reduce allergic disease in mice models } \\
\text { of acute asthma }\end{array}$ & $\begin{array}{l}\text { CD80/86 co-stimulation does not } \\
\text { contribute to recall responses of effector } \\
\text { Th2 cells [156] and might not be useful } \\
\text { for the treatment of established disease }\end{array}$ \\
\hline & OX40L & Anti-OX40L Ab & $\begin{array}{l}\text { Blocks Th2 cell infiltration, cytokine } \\
\text { secretion, lgE production and Th2 } \\
\text { inflammation in mouse and non-human } \\
\text { primate models [157] }\end{array}$ & - \\
\hline & $\begin{array}{l}\text { Programmed } \\
\text { death-1 (PD-1) } \\
\text { and PD1 } \\
\text { ligands }\end{array}$ & None so far & $\begin{array}{l}\text { PD-1 and its ligands regulate T cell } \\
\text { activation and differentiation and affect } \\
\text { asthmatic responses [158] }\end{array}$ & - \\
\hline \multirow[t]{3}{*}{ Macrophage } & $\begin{array}{l}\text { Anti-A1 } \\
\text { adenosine } \\
\text { receptors }\end{array}$ & $\begin{array}{l}\text { A1 adenosine receptor } \\
\text { modulators }\end{array}$ & Anti-inflammatory [159] & $\begin{array}{l}\text { Gene expression and function depends } \\
\text { on polarisation (classical vs. alternative } \\
\text { activation) [160] }\end{array}$ \\
\hline & Unknown & Water-soluble chitosan & Suppresses allergic asthma in mice [161] & \\
\hline & Unknown & Mycolic acid & $\begin{array}{l}\text { Modulates airway macrophage function } \\
\text { to suppress allergic inflammation in mice } \\
\text { [162] }\end{array}$ & \\
\hline Basophil & $\begin{array}{l}\text { Specific target } \\
\text { unknown so } \\
\text { far }\end{array}$ & N/A & $\begin{array}{l}\mathrm{CD}_{49} \mathrm{~b}^{+} \mathrm{Fc \varepsilon R} \mathrm{R}^{+} \text {basophils migrate from } \\
\text { blood to lymph nodes, where they } \\
\text { present processed antigen to T cells in } \\
\text { the context of MHC class II molecules } \\
\text { and induce Th2 type polarisation } \\
\text { through secretion of IL-4 [163-166] }\end{array}$ & $\begin{array}{l}\text { Recently, the role of basophils in Th2 } \\
\text { immunity was disputed in favour of } \\
\text { inflammatory DCs }[167,168]\end{array}$ \\
\hline
\end{tabular}

CXCR4 is also involved in Th2 cell migration into the lungs [58] and treatment of allergic mice with selective CXCR4 inhibitors significantly reduces AHR and inflammatory responses $[59,60]$, supporting the further development of CXCR4 antagonists for asthma treatment. CCR3, which regulates eosinophil and mast cell accumulation into the lungs [61], is expressed on Th2 lymphocytes [62]. CCR3 inhibition is a promising Th2 cell target that reduces innate and adaptive allergic inflammation [63]. TPI ASM8 is a compound that contains modified antisense oligonucleotides targeting CCR3 and the common beta chain of the receptors of GM-CSF, IL-5 and IL-13, decreases airway inflammation in humans after allergen exposure and is under clinical evaluation [64]. Other CKRs that appear to regulate CD4+ T cell homing to the lungs in asthma include CCR5, CCR6, CCR7 and CXCR3 [65-67]. CCR7 is a CKR expressed on a large number of naïve and memory $T$ cells [47] and therefore does not represent suitable target. Expression of CCR5, CCR6 and CXCR3 is related to Th1 (CXCR3 and CCR5) $[48,49]$ or Th17 (CCR6) cells [68]. Thus, it is possible that CKR agonists, rather than antagonists, might inhibit Th2 cells in asthma. Importantly, the chemokine system is highly redundant with promiscuous chemokine-CKR interactions, suggesting that a single chemokine or CKR could have compensatory mechanisms leading to unexpected side effects. Moreover, blocking of a single chemokine or 
Table 2 Strategies to inhibit Th2 cell differentiation

\begin{tabular}{|c|c|c|c|c|}
\hline Target & Mechanism & Intervention example & Effect & Comment \\
\hline GATA-3 & $\begin{array}{l}\text { Development of Th2 cells } \\
\text { [169] }\end{array}$ & $\begin{array}{l}\text { Local treatment with GATA-3 antisense } \\
\text { oligonucleotides [170] or RNA } \\
\text { interference delivered by a lentiviral } \\
\text { vector [171] }\end{array}$ & Inhibits allergen-induced asthma & $\begin{array}{l}\text { Important for T cell } \\
\text { development, its } \\
\text { inhibition could cause } \\
\text { immunosuppression [169] }\end{array}$ \\
\hline STAT3 & $\begin{array}{l}\text { Important for } \\
\text { differentiation of Th2 cells } \\
{[172]}\end{array}$ & Selective small molecule inhibitors [173] & Inhibits allergen-induced asthma & - \\
\hline STAT5a & $\begin{array}{l}\text { Important for } \\
\text { differentiation of Th2 cells }\end{array}$ & None known & $\begin{array}{l}\text { STAT-5a deficient mice have } \\
\text { decreased IL-5 production and Th2 } \\
\text { and eosinophil recruitment in mouse } \\
\text { model of asthma [174] }\end{array}$ & $\begin{array}{l}\text { Also important for } \\
\text { development of inducible } \\
\text { Tregs [175] }\end{array}$ \\
\hline STAT6 & $\begin{array}{l}\text { Important for } \\
\text { differentiation of Th2 cells }\end{array}$ & $\begin{array}{l}\text { Selective small molecule inhibitors [176] } \\
\text { or RNA interference [177] of STAT6 }\end{array}$ & $\begin{array}{l}\text { Suppresses Th2 responses in vitro and } \\
\text { in animal models }\end{array}$ & - \\
\hline Notch & $\begin{array}{l}\text { Binds to the promoter of } \\
\text { GATA-3 and regulates its } \\
\text { transcription }[178,179]\end{array}$ & Gamma-secretase inhibitor (GSI) [180] & $\begin{array}{l}\text { Selective inhibition of Th2, but not } \\
\text { Th1 responses [181] }\end{array}$ & $\begin{array}{l}\text { Involved in development } \\
\text { of many other leukocytes } \\
\text { and organs }[182,183]\end{array}$ \\
\hline c-Maf & $\begin{array}{l}\text { Transcription factor } \\
\text { expressed at high levels in } \\
\text { Th2 cells }[184,185]\end{array}$ & $\begin{array}{l}\text { So-Cheong-Ryong-Tang (a Korean } \\
\text { traditional medicine; [186]) or KR62890 } \\
\text { (agonist of peroxisome proliferator- } \\
\text { activated receptor } \gamma_{;}[187] \text { ) }\end{array}$ & Inhibits Th2 cell functions & $\begin{array}{l}\text { Inhibits Th-17 and Treg } \\
\text { function }\end{array}$ \\
\hline $\begin{array}{l}\text { Gfi-1, } \\
\text { Dec2, } \\
\text { ROG and } \\
\text { BCl-6 }\end{array}$ & $\begin{array}{l}\text { Transcription repressors } \\
\text { important for Th2 cell } \\
\text { development [188-192] }\end{array}$ & None known & N/A & - \\
\hline sOCS-3 & $\begin{array}{l}\text { Inhibitor of cytokine } \\
\text { signalling pathways [193] }\end{array}$ & None known & $\begin{array}{l}\text { SOCS-3 blocks Th1 cell development } \\
\text { and is preferentially expressed in Th2 } \\
\text { cells [194] }\end{array}$ & $\begin{array}{l}\text { Appears to be involved in } \\
\text { Treg and/or Th17 cell } \\
\text { development [195] }\end{array}$ \\
\hline SOCS-5 & $\begin{array}{l}\text { Inhibitor of cytokine } \\
\text { signalling pathways [193] }\end{array}$ & None known & $\begin{array}{l}\text { Preferentially expressed in Th1 cells } \\
\text { and prevents Th2 cell development } \\
\text { [196] }\end{array}$ & $\begin{array}{l}\text { Its over-expression in T } \\
\text { cells enhances airway } \\
\text { inflammation and AHR } \\
\text { [197] }\end{array}$ \\
\hline $\begin{array}{l}\text { miRNA- } \\
16, \\
\text { miRNA- } \\
21 \\
\text { miRNA- } \\
126\end{array}$ & $\begin{array}{l}\text { Up-regulated in lung } \\
\text { tissue after allergen } \\
\text { challenge in mouse } \\
\text { models of asthma } \\
{[198,199]}\end{array}$ & $\begin{array}{l}\text { Anti-miRNA-126 antagomir (small } \\
\text { synthetic RNA molecule with modified } \\
\text { backbone for degradation prevention) } \\
{[199]}\end{array}$ & $\begin{array}{l}\text { Prevents allergen-induced airway } \\
\text { hyperreactivity and reduces allergic } \\
\text { inflammation }\end{array}$ & - \\
\hline
\end{tabular}

CKR might also not have an effect due to this redundancy.

CRTH2 is a mediator involved in the migration and activation of basophils, eosinophils and Th2 cells $[69,70]$. CRTH2 inhibition leads to attenuated airway hyperreactivity and inflammation in animal models [71]. Ramatroban, a dual thrombroxane A2 receptor (TP) and CRTH2 receptor antagonist, suppresses eosinophil chemotaxis in vitro and in vivo and is approved for the treatment of allergic rhinitis in Japan [72]. Numerous other CRTH2 antagonists, such as 4-aminotetrahyrochinoline derivatives or indoleacetic acid derivatives, are currently under development $[69,70,72]$ and OC000459 is in clinical trials for the treatment of allergic asthma (ClinicalTrials.gov identifier: NCT01057927, NCT00 890877). The CRTH2 receptor is a DP2 receptor. Biological effects of PGD2 and PGH2 are mediated by D prostanoid receptor 1 (DP1) and CRTH2 (DP2). PGD2 activates DP1, thereby affecting NK cells and their cytokine production into a profile more favourable for Th2 skewing [73]. PGH2 is implicated in the accumulation of CRTH2+ cells at sites of inflammation [74]. Additionally, as discussed above, PGE2 polarises DCs to promote Th2 cell differentiation and recruitment [34,36,37]. These effects of PGE2 seem to be mediated by PGE2 receptor type 2 (EP2) and type 4 (EP4) [75]. Therefore, PGs and CRTH2 appear to be promising Th2 cell-specific targets.

While homing receptors are important for Th2 cell migration, several adhesion molecules also play a role. For example, intercellular adhesion molecule (ICAM)-1 and ICAM-2 play important roles in $\mathrm{T}$ cell migration in the lungs [76] and ICAM-1 deficiency reduces leukocyte infiltration into the airways, as well as IL-4 and IL-5 concentration in bronchoalveolar lavage fluid [77]. Additionally, VCAM-1 plays a role in eosinophil migration and activation in addition to $\mathrm{T}$ cell trafficking [78]. There are no clinical data to date for mAbs against ICAM-1 or VCAM-1 in the treatment of asthma. Other potential adhesion targets include VLA-4 ( $\alpha 4 \beta 1$ 
Table 3 Interference with Th2 signal transduction pathway and their inhibitors

\begin{tabular}{|c|c|c|c|}
\hline Class & $\begin{array}{l}\text { Examples of } \\
\text { inhibitor(s) }\end{array}$ & Effect & Reference* \\
\hline EGF receptor inhibitor & Gefitinib & $\begin{array}{l}\text { Reduces the cell counts and Th2 cytokine levels in an OVA- } \\
\text { challenged mouse model of allergic asthma }\end{array}$ & {$[200]$} \\
\hline \multirow[t]{2}{*}{ Syk inhibitors } & BAY 61-3606 & Inhibits disease signs in a mouse model of asthma & [201] \\
\hline & $\mathrm{R} 112$ & Reduces allergic rhinitis upon intranasal administration & {$[202]$} \\
\hline \multirow[t]{2}{*}{ JAK3 inhibitors } & CP690550 & Blocks expression and signalling of IL-2, IL-4 and IL-13 & [203] \\
\hline & $\begin{array}{l}\text { WHI-P131 and WHI- } \\
\text { P97 }\end{array}$ & $\begin{array}{l}\text { Interferes with inflammatory mediators and mast cell } \\
\text { degranulation in animal models of asthma }\end{array}$ & {$[204,205]$} \\
\hline p38 MAPK/ERK inhibitor & U0126 & $\begin{array}{l}\text { Inhibits airway and lung inflammation in mouses model of } \\
\text { asthma } \\
\text { Role of p38 in steroid resistant asthma patients is investigated } \\
\text { in a clinical trial }\end{array}$ & $\begin{array}{l}{[206]} \\
\text { NCT00676572 }\end{array}$ \\
\hline Inhaled p38 MAPK antisense oligonucleotide & ISIS101757 & Inhibits allergic immunity in mice & [207] \\
\hline p38 $\alpha$ inhibitors & $\begin{array}{l}\text { BIRB796, SB203580 } \\
\text { and RWJ67657 }\end{array}$ & $\begin{array}{l}\text { Inhibits airway and lung inflammation in mouse models of } \\
\text { asthma }\end{array}$ & {$[208-210]$} \\
\hline JNK inhibitor & SP600125 & $\begin{array}{l}\text { Inhibits T cell cytokine production and lung inflammation in } \\
\text { mouse models of asthma }\end{array}$ & {$[211,212]$} \\
\hline $\begin{array}{l}\text { Inhibitor of adenosine } \mathrm{A} 1, \mathrm{~A} 2 \mathrm{~b} \text { and } \mathrm{A} 3 \\
\text { receptors, } \mathrm{p} 38 \mathrm{MAPK} \text { and PDE4D }\end{array}$ & $\mathrm{CGH} 2466$ & Inhibits allergic asthma in mice & [213] \\
\hline PI3K inhibitors & $\begin{array}{l}\text { Wortmannin and } \\
\text { Ly294002 }\end{array}$ & Inhibits allergic asthma in mice & {$[214,215]$} \\
\hline Inhibitor of IkappaB kinase-2 (IKK-2) & N/A & $\begin{array}{l}\text { Reduces allergen-induced airway inflammation and AHR in } \\
\text { animal models of asthma }\end{array}$ & {$[216,217]$} \\
\hline IkappaB ubiquitination inhibitor & GS143 & $\begin{array}{l}\text { Represses Th2, but not Th1 differentiation after allergen } \\
\text { challenge in a mouse model of allergic asthma }\end{array}$ & {$[218]$} \\
\hline Selective PDE4 inhibitors & GSK256066, MK-0359 & $\begin{array}{l}\text { Inhibits the fall in lung function in patients with asthma caused } \\
\text { by inhaled allergen challenge }\end{array}$ & {$[219,220]$} \\
\hline PDE3 and PDE4 inhibitors & RPL554 & $\begin{array}{l}\text { Inhibits eosinophil recruitment following antigen challenge in } \\
\text { guinea pigs }\end{array}$ & [221] \\
\hline
\end{tabular}

* Numbers starting with NTC represent clinical study code from http://clinicaltrials.gov/

integrin) [79] or P-, E- and L-selectins [80]. Natalizumab blocks both $\alpha 4 \beta 1$ and $\alpha 4 ß 7$ integrins, but was discontinued due to severe side -effects [81]. Novel $\alpha 4$ integrin mAb LLP2A reduces AHR and inflammation in mouse allergic asthma [82]. Unfortunately, initial results with VLA-4 antagonist GW559090 were disappointing [83], but newer and safer alternative VLA-4 antagonists are in development [84-86]. Lastly, a pan-selectin inhibitor is currently in phase IIa clinical trials for COPD, might also be promising for asthma [81]. None of these adhesion molecules is selectively expressed on Th2 cells.

The anticoagulant heparin has anti-inflammatory properties that inhibit leukocyte extravasation [87]. IVX0142 is a heparin-derived hypersulfated disaccharide that appears to be well-tolerated and shows a trend towards attenuation of asthmatic responses, but does not affect AHR [88]. Additional studies are needed to evaluate effects of these molecules on Th2 cells.

\section{Inhibition of long-lived Th2 memory cells}

It is possible that long-lived Th2 memory cells establish anti-apoptotic mechanisms for long-term maintenance, which when inhibited may result in cell death. Interfering with mechanisms for their longevity in the lungs may eliminate Th2 cells. Corticosteroids [89], calcineurin inhibitors [90] and the cysteine leukotriene receptor antagonist montelukast [89] have pro-apoptotic effects on activated $\mathrm{T}$ cells, one of the many mechanisms that lead to their effectiveness in asthma. CX3CR1 seems to provide a survival signal for lung Th2 and Th1 cells, which when inhibited reduces allergic inflammation [67]. $T$ cells from p53-deficient mice have decreased apoptosis and increased Th2 differentiation [91], cytoxic lymphocyte antigen-4 (CTLA-4) promotes $\mathrm{T}$ cell apoptosis $[92,93]$ and CTLA-4-deficient Th cells are directed towards Th2 differentiation [94]. Additionally, the ratio of anti-apoptotic protein Bcl-2 over proapoptotic protein Bax in peripheral blood lymphocytes of asthmatic patients is increased in comparison to healthy controls [95]. Interestingly, Th2 cells express less Fas ligand (FasL) and are more resistant to apoptosis than other Th subtypes [96,97]. Moreover, the Th2 cytokine IL-4 reduces FasL, while Th1 cytokines IFN $\gamma$, TGF $\beta$ and IL-2 increase FasL expression [89]. Regulation of FasL plays an important role because FasLexpressing $\mathrm{T}$ cells are pivotal during the resolution of airway inflammation [98] and intratracheal delivery of DCs co-transfected with FasL and allergen genes before 
Table 4 Effector cytokines as targets

\begin{tabular}{|c|c|c|c|c|}
\hline Cytokine & Relation to Th2 cells in asthma & References & Was the target used in clinical trials in asthma? & $\begin{array}{l}\text { Clinical study, } \\
\text { Reference* }\end{array}$ \\
\hline $\mathrm{IL}-2$ & $\begin{array}{l}\text { Important for survival of mature Tregs } \\
\text { Required for generation of effector and } \\
\text { survival of memory T cells }\end{array}$ & $\begin{array}{l}{[175]} \\
{[222]}\end{array}$ & $\begin{array}{l}\text { Yes, daclizumab targeting its soluble } \mathrm{IL}-2 \text { receptor } \mathrm{CD} 25 \text {, } \\
\text { improves } \mathrm{FEV}_{1} \text { and reduced daily asthma symptoms }\end{array}$ & NCT00028288 \\
\hline IL-3 & $\begin{array}{l}\text { Secreted by Th2 cells, regulates eosinophil } \\
\text { and basophil differentiation, migration } \\
\text { and survival } \\
\text { Inhibition of IL-3/LL-5/GM-CSF common } \beta \\
\text { receptor inhibits Th2 differentiation }\end{array}$ & $\begin{array}{l}{[223,224]} \\
{[225]}\end{array}$ & No & - \\
\hline $\mathrm{IL}-4$ & $\begin{array}{l}\text { Crucial for Th2 cell differentiation } \\
\text { Induction of IgE production of B cells }\end{array}$ & {$[226]$} & $\begin{array}{l}\text { Yes, numerous mAbs and other compounds, development } \\
\text { of most mAbs was discontinued, pitrakinra (IL-4 mutant } \\
\text { protein binding to IL-4 and IL-13 receptors) improves lung } \\
\text { function, stabilises asthma symptom scores and reduces } \\
\text { beta-agonist use }\end{array}$ & $\begin{array}{l}{[9,11,227-229]} \\
\text { NCT00801853, } \\
\text { NCT00941577 }\end{array}$ \\
\hline $\mathrm{IL}-5$ & $\begin{array}{l}\text { Th2 cell cytokine involved in eosinophil } \\
\text { differentiation, maturation, recruitment } \\
\text { and survival }\end{array}$ & {$[230,231]$} & $\begin{array}{l}\text { Yes, does not inhibit eosinophilia or AHR, but new } \\
\text { indications suggest use in difficult-to-treat and severe } \\
\text { asthma }\end{array}$ & $\begin{array}{l}{[232-234]} \\
\text { NCT01000506, } \\
\text { NCT00292877 }\end{array}$ \\
\hline IL-6 & $\begin{array}{l}\text { Polarises CD4+ T cells to Th2 or Th17 } \\
\text { subtype } \\
\text { Soluble IL-6 receptor induces apoptosis of } \\
\text { Th2 cells in the lungs \& induces Tregs }\end{array}$ & $\begin{array}{l}{[235,236]} \\
{[237]}\end{array}$ & No & - \\
\hline IL-9 & $\begin{array}{l}\text { Secreted by Th2 cells } \\
\text { Over expression in mice enhances } \\
\text { inflammation and AHR }\end{array}$ & $\begin{array}{l}{[238]} \\
{[239,240]}\end{array}$ & $\begin{array}{l}\text { Yes, appears to have acceptable safety profile and to } \\
\text { decrease FEV } V_{1}\end{array}$ & {$[241,242]$} \\
\hline $\mathrm{IL}-10$ & $\begin{array}{l}\text { Secreted by Th2 cells and some Tregs, } \\
\text { plays multiple roles in the immune } \\
\text { processes }\end{array}$ & [243] & No & - \\
\hline $\mathrm{IL}-12$ & $\begin{array}{l}\text { Essential for differentiation, proliferation } \\
\text { and activation of Th1 cells } \\
\text { Suppresses Th2 immune responses in } \\
\text { murine models }\end{array}$ & $\begin{array}{l}{[244]} \\
{[245]}\end{array}$ & $\begin{array}{l}\text { Yes, reduction in the number of circulating blood } \\
\text { eosinophils, but not sputum eosinophilia, the late-phase } \\
\text { response or airway hyper-responsiveness }\end{array}$ & {$[246]$} \\
\hline $\mathrm{IL}-13$ & $\begin{array}{l}\text { Involved in lung inflammation, mucus } \\
\text { hypersectretion, subepithelial fibrosis and } \\
\text { eotaxin production }\end{array}$ & [247] & $\begin{array}{l}\text { Yes, clinical trials for numerous mAbs are in progress; } \\
\text { pitrakinra (IL-4 mutant protein binding to IL-4 and IL-13 } \\
\text { receptors) improves lung function, stabilises asthma } \\
\text { symptom scores and reduces beta-agonist use }\end{array}$ & $\begin{array}{l}{[229,248,249]} \\
\text { (NCT00873860, } \\
\text { NCT00801853, } \\
\text { NCT00941577) }\end{array}$ \\
\hline IL-15 & $\begin{array}{l}\text { Th1 cytokine that appears to } \\
\text { counterbalance Th2 immune response }\end{array}$ & {$[250]$} & No & - \\
\hline $\mathrm{IL}-17 \mathrm{~A}$ & $\begin{array}{l}\text { Implicated in infiltration of neutrophils } \\
\text { after allergen exposure } \\
\text { Might regulate established Th2 response }\end{array}$ & $\begin{array}{l}{[251]} \\
{[252]}\end{array}$ & No & - \\
\hline IL-17F & $\begin{array}{l}\text { Implicated in infiltration of neutrophils } \\
\text { after allergen exposure }\end{array}$ & [251] & No & - \\
\hline IL-18 & $\begin{array}{l}\text { Cytokine involved in Th1 and Th2 } \\
\text { immunity } \\
\text { Delivery of IL-18 gene reduced allergic } \\
\text { inflammation in a mouse asthma model }\end{array}$ & $\begin{array}{l}{[253]} \\
{[254]}\end{array}$ & No & - \\
\hline IL-19 & $\begin{array}{l}\text { Produced by epithelial cells and mediates } \\
\text { IL-4, IL-5, IL-10 and IL-13 production }\end{array}$ & {$[255,256]$} & No & - \\
\hline IL-21 & $\begin{array}{l}\text { Secreted by CD4+ T cells } \\
\text { Involved in proliferation, differentiation } \\
\text { and regulation of T cells, B cells, DCs and } \\
\text { natural killer cells } \\
\text { Stimulates IgG responses instead of lgE }\end{array}$ & {$[23,257]$} & No & - \\
\hline IL-22 & $\begin{array}{l}\text { Required for the onset of allergic asthma } \\
\text { in mice, but negatively regulates acute } \\
\text { inflammation in lungs }\end{array}$ & [258] & No & - \\
\hline IL-23 & $\begin{array}{l}\text { Lung-specific expression enhances } \\
\text { allergen-induced inflammation, mucus }\end{array}$ & $\begin{array}{l}{[259]} \\
{[260]}\end{array}$ & No & - \\
\hline
\end{tabular}


Table 4 Effector cytokines as targets (Continued)

\begin{tabular}{|c|c|c|c|c|}
\hline $\mathrm{IL}-25$ & $\begin{array}{l}\text { Induces Th2 immunity, enhances Th2 cell } \\
\text { survival and stimulates Th2 cytokine } \\
\text { secretion } \\
\text { Its inhibition prevents inflammation in } \\
\text { mouse models of asthma }\end{array}$ & {$[261,262]$} & No & - \\
\hline $\mathrm{IL}-27$ & $\begin{array}{l}\text { Th1 cytokine decreases Th2 response in } \\
\text { murine models of asthma }\end{array}$ & {$[263]$} & No & - \\
\hline IL-31 & $\begin{array}{l}\text { Secreted by Th2 cells, expressed at higher } \\
\text { levels in asthmatic patients }\end{array}$ & {$[264,265]$} & No & - \\
\hline $\mathrm{IL}-33$ & $\begin{array}{l}\text { IL-33 receptor, ST2, is a marker for Th2 } \\
\text { cells } \\
\text { IL-33 activates Th2 cells }\end{array}$ & $\begin{array}{l}{[266,267]} \\
{[268]}\end{array}$ & No & - \\
\hline IFN- $\gamma$ & $\begin{array}{l}\text { Th1 cytokine that inhibits Th2 cell } \\
\text { polarisation in vitro } \\
\text { Appears to be involved in pathogenesis } \\
\text { of severe allergic asthma }\end{array}$ & $\begin{array}{l}{[40]} \\
{[269,270]}\end{array}$ & $\begin{array}{l}\text { Yes, but treatment did not improve monitored clinical } \\
\text { parameters }\end{array}$ & {$[271]$} \\
\hline TGF-ß & $\begin{array}{l}\text { TGF-ß inhibits expression of transcription } \\
\text { factor GATA-3 } \\
\text { Its neutralisation exacerbates or has no } \\
\text { effect on inflammatory responses in } \\
\text { mouse models of asthma }\end{array}$ & $\begin{array}{l}{[272]} \\
{[273,274]}\end{array}$ & No & - \\
\hline TNF- $\alpha$ & $\begin{array}{l}\text { Pleiotropic cytokine, chemoattractant for } \\
\text { eosinophils and contributes to the } \\
\text { activation of } T \text { cells }\end{array}$ & {$[275]$} & Yes, divergent results, severe side-effects & {$[276,277]$} \\
\hline
\end{tabular}

* Numbers starting with NTC represent clinical study code from http://clinicaltrials.gov/

allergen challenge-induced $\mathrm{T}$ cell apoptosis and decreased airway inflammation in mice [99]. Induction of Fas expression on Th2 cells might be a possible treatment approach that would decrease their survival in the lungs despite the fact that Th2 cells are somewhat resistant to Fas-induced apoptosis. An additional important pathway for apoptosis in T cells involves granzyme B, which is critical for activation-induced cell death [100]. Inhibition of granzyme B rescues Th2 cells from apoptosis [100], suggesting that selective activation of granzyme B in Th2 cells might be a novel target. Another possibility is that increased apoptosis of Tregs and their protection from apoptosis might be a method of treating disease but there is little information related to cell death of Tregs in allergic diseases and it is possible that dysregulated apoptosis of Tregs may contribute to allergic asthma [90].

\section{New categories of targets: Statins and Rho kinases; TIM proteins; Galectins; Siglecs; Arginases; Histone deacetylase inhibitors; Pathogens and Toll-like receptors} Statins are a class of cholesterol lowering drugs that also possess anti-inflammatory and immune properties $[101,102]$. Simvastatin, Lovastatin and Pravastatin reduced eosinophilia and Th2 cytokines in animal models of asthma [103-105]. Clinical trials evaluating Simvastatin (NCT00792337), Lovastatin (NCT00689806) and Atorvastatin (NCT00463827), are ongoing or completed, but data are not yet available. Some statins exert their action through regulation of Rho kinases [106], which are expressed at high levels in airway smooth muscle and regulate their contractility [107], but inhibition appears to impair lymphocyte cytokine secretion [108].

The genes for the $\mathrm{T}$ cell immunoglobulin domain and mucin domain (TIM) proteins are encoded in the $\mathrm{T}$ cell and airway phenotype regulator region on chromosome 11 [109]. Initial results indicate that although TIM-1 is involved in Th2 cell differentiation and is associated with Th2-mediated diseases [110], it also regulates Th17 and Treg development. Furthermore, TIM proteins are expressed by other immune- cell types [111]. Because TIM proteins do not exclusively regulate Th2 cells, they are less useful as targets than originally anticipated.

Galectins are $\beta$-galactoside-binding proteins that bind to glycan residues on the surface of mammalian cells [112]. Examples are Galectin-3 and -9, which appear to have numerous functions in $\mathrm{T}$ cell activation, differentiation and apoptosis [112]. Airway inflammation and challenge is decreased in Galectin-3 knockout mice [113] and intranasal administration of a plasmid encoding Galectin-3 abates chronic airway inflammation in a murine model of asthma [114]. Galectin-9 binds to TIM-3, which is expressed on Th1 cells and is important for protective immunity against microbes [111] and intravenous administration of Galectin-9 suppresses AHR and airway inflammation in a mouse model of asthma [115].

Siglecs are sialic acid-recognising Ig-superfamily lectins [116]. CD33-related Siglecs, which in humans 
include Siglec-3 and Siglecs-5 through -11, are predominantly found on human leukocytes and involved in innate immunity $[116,117]$. Mouse Siglec-F, the equivalent of human Siglec-8, is expressed on eosinophils and regulates their apoptosis [118]. Blocking Siglec-F function with a $\mathrm{mAb}$ reduces airway and lung eosinophilia in mice [119]. Although Siglec-8 is a promising target directed against eosinophils, human $\mathrm{T}$ lymphocytes express little or no siglec molecules [120] and do not appear to be a candidate for inhibiting Th2 cells.

Arginase I and II are cationic amino acid transporters involved in the metabolism of basic amino acids expressed in inflammatory lesions of patients with allergic asthma [121-123]. Arginase gene expression and enzyme activity are enhanced by IL-4 and IL-13 $[122,123]$. Inhibition of arginase I by RNA interference suppresses IL-13-mediated AHR in a murine model of asthma [124] and inhalation of an arginase inhibitor decreases AHR and airway inflammation in a guinea pig model of asthma [122]. Conversely, deletion of arginase in macrophages impairs their ability to suppress Th2dependent inflammation and fibrosis [125]. Further research is needed in order to clarify the role of arginases in Th2 immunity.

Histone deacetylases (HDAC) appear to play an important role in cytokine transcription [126]. Corticosteroid signalling requires $\mathrm{HDAC} 2$ to suppress inflammatory gene products and $\mathrm{HDAC} 2$ activity is diminished in corticosteroid-resistance [9]. HDAC inhibitor Trichostatin A reduces allergic airway inflammation by decreasing expression of the Th2 cytokines, IL-4, IL-5 and IgE [127]. In contrast, HDAC1 appears to be a negative regulator of Th2 cytokine expression [128]. Chromatin modification enzymes might be potential targets for inhibition of Th2-mediated diseases.

Many microbials or their proteins inhibit Th2 immune responses in murine models of asthma by polarising towards Th1 immunity [129-131] or by generating suppressive Tregs [132,133]. Interestingly, microbial agents have both time- and dose-dependent effects on allergic asthma $[134,135]$. Certain allergens such as dust mite Der p2 and Der f2, bind LPS and are related to the MD-2 protein of the LPS-binding component of the TLR4 signalling complex $[136,137]$, which might influence the induction of Th2 responses demonstrating a potential for microbials augmenting rather than reducing Th2 responses. Alternatively, bacterial DNA or chemically synthesised de novo unmethylated $\mathrm{CpG}$ are immunostimulatory ligands that bind to TLR9 and induce strong Th1 immune responses [reviewed in [138]]. Such bacterial and synthetic DNA immunostimulatory oligonucleotides (ISS-ODNs) containing CpG motifs suppress Th2 responses during the sensitisation phase or immediately before challenge in experimental asthma [reviewed in [139]]. They have therapeutic and prophylactic properties [140], including suppression of DC migration and co-stimulatory molecule expression and inhibition of IgE-dependent Th2 cytokine release from mast cells and basophils [141,142]. Moreover, ISSODNs added to allergen immunotherapy significantly reduce clinical symptoms in patients with asthma [143].

\section{Conclusions}

Th2 cells and/or their secreted effector molecules mediate the immune response to allergens and are triggered by exposure to specific allergens leading to allergic asthma. Thus, inhibiting or eliminating Th2 cells is a beneficial strategy for treating asthma as long as generalised immunosuppression is avoided. Additionally, it is especially important to consider targeting Th2 cells early in disease because when disease is chronic additional factors may cause perpetuation. Although there are a myriad of potential Th2 targets (Figure 2), the

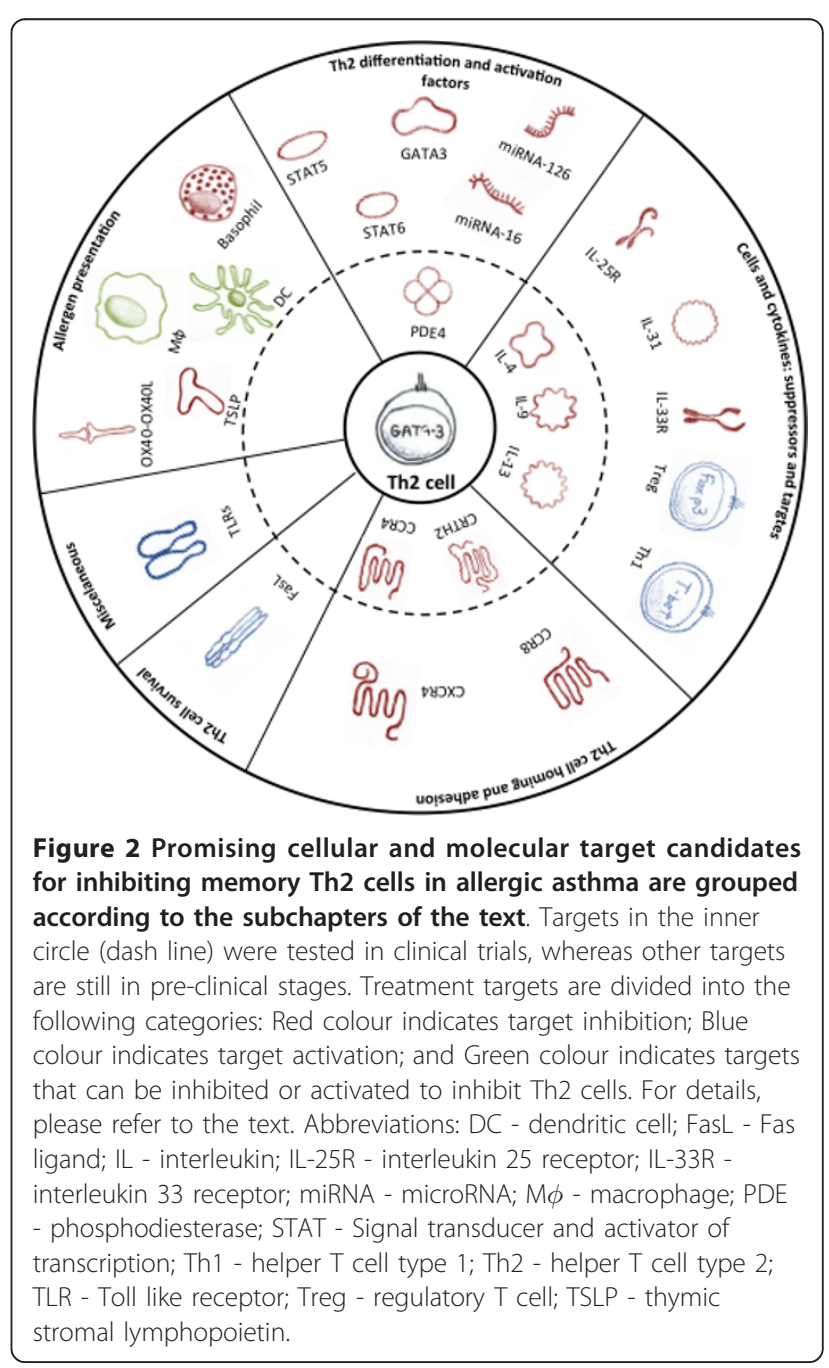


optimal, most effective anti-Th2 cell target for the clinic remains elusive.

Aside from anti-IgE therapy for severe asthma, there are no major new drugs for the treatment of asthma in the last 20 years. The latest research in allergic asthma that has elucidated key factors governing Th2 immunity and identified potential targets is predominantly from animal models. Now, the challenge is to discover candidates, which best translate from animal models to patients. However, choosing the most effective new drug target candidate is especially difficult because human data is often lacking or incomplete. Additionally, the use of accurate, predictive biomarkers to evaluate Th2-modulating drugs such as FEV1, Quality of Life, reduction in steroid use, decrease allergen-induced late phase response and others are important to ensure that the efficacy/adverse effect profiles are standardised and enable easier decision-making for the best candidates. We would argue that the most promising new compounds for the clinic are those in which proof of concept in patients is established e.g. anti-IL-13 antibodies and CRTH2 antagonists. Other candidates currently tested in the clinic are anti-IL-5, anti-IL-4 and anti-IL-9 compounds and CCR4 antagonists. However, based on available human data, we suggest that the epithelial cellderived cytokines TSLP, IL-25 and IL-33, which drive Th2 responses are the most promising candidates, with TLSP the clear frontrunner.

Steroids are efficient for treating asthma because they inhibit numerous pro-inflammatory responses and induce numerous anti-inflammatory pathways. Thus, targeting a single mediator may not suffice for the treatment of allergic asthma because of the redundant immune and inflammatory pathways involved upon allergen challenge. Thus, we suggest that targeting more than one molecule simultaneously using dual specific antibody/protein platforms to engineer new drugs will be the next major approach in drug discovery. However, while this approach creates a scenario in which numerous targets can be combined, the caveat is that optimal candidates must be carefully chosen. Another important consideration for the therapeutic strategy for allergic asthma is that drugs may need to be developed for specific subtypes of disease in which particular cellular and molecular pathways drive the disease. One example is the anti-IL-5 mAb, which is only effective in asthmatics with very high sputum and lung eosinophil numbers. This example suggests that it is beneficial to better categorise patients and consider personalised medicine based on a clear classification of disease.

These are exciting times for Th2 cell immunology as the results of basic research are defining key molecular and cellular components in the response to allergens. This information is already being converted to targets that are being tested in the clinic. Currently, irrespective of approach, we consider that a successful strategy for the treatment of allergic asthma will include a selective inhibition of Th2 cells with the ultimate aim of eliminating allergen-specific Th2 immune responses. We anticipate that new candidates will be approved in the near future and offer treatment options for patients suffering with asthma and other allergic diseases.

\section{List of abbreviations}

AHR: Airway hyperresponsiveness; Al: Allergen immunotherapy; APC: Antigen presenting cell BCl: B cell lymphoma; Th: CD4+ T helper; CKR: Chemokine receptor; CRTH2: Chemoattractant receptor-homologous molecule expressed on TH2 cells; CpG: Cytosine-guanine dinucleotides; CpG-ODN: Cytosinephosphate-guanine oligonucleotides; CTLA-4: Cytoxic lymphocyte antigen- 4; DC: Dendritic cell; DP1: D prostanoid receptor 1; EGF: Epidermal growth factor; ERK: Extracellular signal regulated kinase FasL: Fas ligand; GM-CSF: Granulocyte-macrophage colony-stimulating factor; HDAC: Histone deacetylases; Ig: Immunoglobulin; ISS-ODNs: Immunostimulatory oligodeoxynucleotides; ICAM: Intercellular adhesion molecule; IFN: Interferon; IL: Interleukin; JAK: Janus kinase; JNK: Jun kinase mAb: monoclonal antibody; MAPK: Mitogen-activated protein kinases; PDE: Phosphodiesterase; PI3K: Phosphoinositide 3-kinase; PD-1: Programmed death-1; PG: Prostaglandin; Siglec: Sialic acid binding Ig-like lectins; STAT: Signal transducer and activator of transcription; SOCS: Suppressor of cytokine signalling; Treg: regulatory T cell; TSLP: Thymic stromal lymphopoietin; TLR: Toll-like receptor; TGF:

Transforming growth factor; TNF: Tumour necrosis factor; VCAM: Vascular cell adhesion molecule; VLA: Very late antigen.

\section{Acknowledgements}

We would like to thank Drs. P. Stuetz and O. Hoffmann for their critical reading of the manuscript, discussions and support. We acknowledge the support for Berislav Bosnjak from the P3AGl project funded by the European Commission through an FP7- IAPP Marie Curie Action - (GA 230739).

\section{Author details}

'Department of Dermatology, DIAID, Experimental Allergy Laboratory, Medical University of Vienna, Vienna, Austria. ${ }^{2}$ Boerhingerlngelheim Pharma, Respiratory Diseases Research, Biberach an der Riss, Germany.

\section{Authors' contributions}

$\mathrm{BB}$ - was involved in drafting the manuscript, revising it critically for important intellectual content; and has given final approval of the version to be published.

BS - made substantial contributions to conception of the review, was involved in drafting the manuscript, revising it critically for important intellectual content; and has given final approval of the version to be published.

KE - made substantial contributions to conception of the review, was involved in drafting the manuscript, revising it critically for important intellectual content; and has given final approval of the version to be published.

ME - made substantial contributions to conception of the review, was involved in drafting the manuscript, revising it critically for important intellectual content; and has given final approval of the version to be published.

\section{Competing interests}

Berislav Bosnjak - was employee of GlaxoSmithKline Research Centre Zagreb Ltd. until December 2008. No other competing interests. Barbara Stelzmüller - none

Klaus J. Erb - is an employee of Boerhingerlngelheim Pharma, Respiratory Diseases Research, Biberach an der Riss, Germany

Michelle M. Epstein - received funding from Boerhingerlngelheim Pharma, Respiratory Diseases Research, Biberach an der Riss, Germany for collaborative project 
Received: 3 May 2011 Accepted: 25 August 2011

Published: 25 August 2011

\section{References}

1. Garlisi CG, Falcone A, Kung TT, Stelts D, Pennline KJ, Beavis AJ, Smith SR, Egan RW, Umland SP: T cells are necessary for Th2 cytokine production and eosinophil accumulation in airways of antigen-challenged allergic mice. Clin Immunol Immunopathol 1995, 75:75-83.

2. Leigh R, Ellis R, Wattie JN, Hirota JA, Matthaei Kl, Foster PS, O'Byrne PM, Inman MD: Type 2 cytokines in the pathogenesis of sustained airway dysfunction and airway remodeling in mice. Am J Respir Crit Care Med 2004, 169:860-867.

3. Larche M, Robinson DS, Kay AB: The role of T lymphocytes in the pathogenesis of asthma. J Allergy Clin Immunol 2003, 111:450-463.

4. Robinson DS, Hamid Q, Ying S, Tsicopoulos A, Barkans J, Bentley AM, Corrigan C, Durham SR, Kay AB: Predominant TH2-like bronchoalveolar Tlymphocyte population in atopic asthma. N Engl J Med 1992, 326:298-304.

5. Mojtabavi N, Dekan G, Stingl G, Epstein MM: Long-Lived Th2 Memory in Experimental Allergic Asthma. J Immunol 2002, 169:4788-4796.

6. Blackburn MR, Lee CG, Young HW, Zhu Z, Chunn JL, Kang MJ, Banerjee SK, Elias JA: Adenosine mediates IL-13-induced inflammation and remodeling in the lung and interacts in an IL-13-adenosine amplification pathway. J Clin Invest 2003, 112:332-344.

7. Wills-Karp M, Luyimbazi J, Xu X, Schofield B, Neben TY, Karp CL, Donaldson DD: Interleukin-13: central mediator of allergic asthma. Science 1998, 282:2258-2261.

8. Zhu Z, Lee CG, Zheng T, Chupp G, Wang J, Homer RJ, Noble PW, Hamid Q, Elias JA: Airway inflammation and remodeling in asthma. Lessons from interleukin 11 and interleukin 13 transgenic mice. Am J Respir Crit Care Med 2001, 164:567-70.

9. Adcock IM, Caramori G, Chung KF: New targets for drug development in asthma. Lancet 2008, 372:1073-1087.

10. Bateman ED, Hurd SS, Barnes PJ, Bousquet J, Drazen JM, FitzGerald M, Gibson P, Ohta K, O'Byrne P, Pedersen SE, et al: Global strategy for asthma management and prevention: GINA executive summary. Eur Respir J 2008, 31:143-178.

11. Caramori G, Groneberg D, Ito K, Casolari P, Adcock IM, Papi A: New drugs targeting Th2 lymphocytes in asthma. J Occup Med Toxicol 2008, 3(Suppl 1):S6.

12. James LK, Durham SR: Update on mechanisms of allergen injection immunotherapy. Clin Exp Allergy 2008, 38:1074-1088

13. Esch RE: Sublingual immunotherapy. Curr Opin Otolaryngol Head Neck Surg 2008, 16:260-264.

14. Rolland JM, Gardner LM, O'Hehir RE: Allergen-related approaches to immunotherapy. Pharmacol Ther 2009, 121:273-284.

15. Reefer AJ, Carneiro RM, Custis NJ, Platts-Mills TA, Sung SS, Hammer J, Woodfolk JA: A role for IL-10-mediated HLA-DR7-restricted T celldependent events in development of the modified Th2 response to cat allergen. J Immunol 2004, 172:2763-2772.

16. Niederberger V: Allergen-specific immunotherapy. Immunol Lett 2009, 122:131-133

17. Saltoun C, Avila PC: Advances in upper airway diseases and allergen immunotherapy in 2007. J Allergy Clin Immunol 2008, 122:481-487.

18. Valenta R, Niederberger V: Recombinant allergens for immunotherapy. J Allergy Clin Immunol 2007, 119:826-830.

19. Qiu J, Li GP, Liu ZG, Ran PX, Zhong NS: DNA vaccine encoding Der p2 allergen down-regulates STAT6 expression in mouse model of allergeninduced allergic airway inflammation. Chin Med J (Engl) 2006, 119:185-190.

20. Crameri R, Fluckiger S, Daigle I, Kundig T, Rhyner C: Design, engineering and in vitro evaluation of MHC class-II targeting allergy vaccines. Allergy 2007, 62:197-206.

21. Schabussova I, Wiedermann U: Lactic acid bacteria as novel adjuvant systems for prevention and treatment of atopic diseases. Curr Opin Allergy Clin Immunol 2008, 8:557-564.

22. Larche M: Peptide immunotherapy for allergic diseases. Allergy 2007, 62:325-331.

23. Holgate ST, Polosa R: Treatment strategies for allergy and asthma. Nat Rev Immunol 2008, 8:218-230

24. Marazuela EG, Prado N, Moro E, Fernandez-Garcia H, Villalba M, Rodriguez $R$, Batanero E: Intranasal vaccination with poly(lactide-co-glycolide) microparticles containing a peptide T of Ole e 1 prevents mice against sensitization. Clin Exp Allergy 2008, 38:520-528.

25. Medoff BD, Seung E, Hong S, Thomas SY, Sandall BP, Duffield JS, Kuperman DA, Erle DJ, Luster AD: CD11b+ myeloid cells are the key mediators of Th2 cell homing into the airway in allergic inflammation. J Immunol 2009, 182:623-635.

26. Rivas-Carvalho A, Meraz-Rios MA, Santos-Argumedo L, Bajana S, Soldevila G, Moreno-Garcia ME, Sanchez-Torres C: CD16+ human monocyte-derived dendritic cells matured with different and unrelated stimuli promote similar allogeneic Th2 responses: regulation by pro- and antiinflammatory cytokines. Int Immunol 2004, 16:1251-1263.

27. Yerkovich ST, Roponen M, Smith ME, McKenna K, Bosco A, Subrata LS, Mamessier E, Wikstrom ME, Le Souef P, Sly PD, et al: Allergen-enhanced thrombomodulin (blood dendritic cell antigen 3, CD141) expression on dendritic cells is associated with a TH2-skewed immune response. $J$ Allergy Clin Immunol 2009, 123:209-216, e204.

28. Hammad H, de Vries VC, Maldonado-Lopez R, Moser M, Maliszewski C, Hoogsteden HC, Lambrecht BN: Differential capacity of CD8+ alpha or CD8- alpha dendritic cell subsets to prime for eosinophilic airway inflammation in the T-helper type 2-prone milieu of the lung. Clin Exp Allergy 2004, 34:1834-1840.

29. Bertorelli G, Bocchino V, Zhou X, Zanini A, Bernini MV, Damia R, Di Comite V, Grima P, Olivieri D: Dendritic cell number is related to IL-4 expression in the airways of atopic asthmatic subjects. Allergy 2000, 55:449-454.

30. Moller GM, Overbeek SE, Van Helden-Meeuwsen CG, Van Haarst JM, Prens EP, Mulder PG, Postma DS, Hoogsteden HC: Increased numbers of dendritic cells in the bronchial mucosa of atopic asthmatic patients: downregulation by inhaled corticosteroids. Clin Exp Allergy 1996 26:517-524.

31. Bratke $K$, Lommatzsch M, Julius $P$, Kuepper M, Kleine HD, Luttmann W, Christian Virchow J: Dendritic cell subsets in human bronchoalveolar lavage fluid after segmental allergen challenge. Thorax 2007, 62:168-175

32. Chen XQ, Yang J, Hu SP, Nie HX, Mao GY, Chen HB: Increased expression of CD86 and reduced production of IL-12 and IL-10 by monocytederived dendritic cells from allergic asthmatics and their effects on Th1and Th2-type cytokine balance. Respiration 2006, 73:34-40.

33. Hammad H, Charbonnier AS, Duez C, Jacquet A, Stewart GA, Tonnel AB, Pestel J: Th2 polarization by Der $\mathrm{p}$ 1-pulsed monocyte-derived dendritic cells is due to the allergic status of the donors. Blood 2001, 98:1135-1141.

34. Long JA, Fogel-Petrovic M, Knight DA, Thompson PJ, Upham JW: Higher prostaglandin e2 production by dendritic cells from subjects with asthma compared with normal subjects. Am J Respir Crit Care Med 2004, 170:485-491

35. Hammad H, Lambrecht BN, Pochard P, Gosset P, Marquillies P. Tonnel AB, Pestel J: Monocyte-derived dendritic cells induce a house dust mitespecific Th2 allergic inflammation in the lung of humanized SCID mice: involvement of CCR7. J Immunol 2002, 169:1524-1534.

36. Kalinski P, Schuitemaker JH, Hilkens CM, Kapsenberg ML: Prostaglandin E2 induces the final maturation of IL-12-deficient CD1a+CD83+ dendritic cells: the levels of IL-12 are determined during the final dendritic cell maturation and are resistant to further modulation. J Immunol 1998, 161:2804-2809.

37. Mcllroy A, Caron G, Blanchard S, Fremaux I, Duluc D, Delneste Y, Chevailler A, Jeannin P: Histamine and prostaglandin E up-regulate the production of Th2-attracting chemokines (CCL17 and CCL22) and downregulate IFN-gamma-induced CXCL10 production by immature human dendritic cells. Immunology 2006, 117:507-516.

38. Ito T, Wang YH, Duramad O, Hori T, Delespesse GJ, Watanabe N, Qin FX, Yao Z, Cao W, Liu YJ: TSLP-activated dendritic cells induce an inflammatory Thelper type 2 cell response through OX40 ligand. J Exp Med 2005, 202:1213-1223.

39. Shi L, Leu SW, XU F, Zhou X, Yin H, Cai L, Zhang L: Local blockade of TSLP receptor alleviated allergic disease by regulating airway dendritic cells. Clin Immunol 2008, 129:202-210.

40. Zhu J, Paul WE: CD4 T cells: fates, functions, and faults. Blood 2008, 112:1557-1569.

41. Zhang DH, Cohn L, Ray P, Bottomly K, Ray A: Transcription factor GATA-3 is differentially expressed in murine Th1 and Th2 cells and controls Th2specific expression of the interleukin-5 gene. J Biol Chem 1997, 272:21597-21603. 
42. Yamashita M, Ukai-Tadenuma M, Miyamoto T, Sugaya K, Hosokawa H, Hasegawa A, Kimura M, Taniguchi M, DeGregori J, Nakayama T: Essential role of GATA3 for the maintenance of type 2 helper T (Th2) cytokine production and chromatin remodeling at the Th2 cytokine gene loci. J Biol Chem 2004, 279:26983-26990.

43. Pai SY, Truitt ML, Ho IC: GATA-3 deficiency abrogates the development and maintenance of T helper type 2 cells. Proc Natl Acad Sci USA 2004, 101:1993-1998.

44. Bi Y, Liu G, Yang R: MicroRNAs: novel regulators during the immune response. J Cell Physiol 2009, 218:467-472.

45. Lodish HF, Zhou B, Liu G, Chen CZ: Micromanagement of the immune system by microRNAs. Nat Rev Immunol 2008, 8:120-130.

46. Garbacki N, Di Valentin E, Huynh-Thu VA, Geurts P, Irrthum A, Crahay C, Arnould T, Deroanne C, Piette J, Cataldo D, Colige A: MicroRNAs profiling in murine models of acute and chronic asthma: a relationship with mRNAs targets. PLoS One 2011, 6:e16509.

47. Bonecchi R, Galliera E, Borroni EM, Corsi MM, Locati M, Mantovani A: Chemokines and chemokine receptors: an overview. Front Biosci 2009, 14:540-551.

48. Annunziato F, Cosmi L, Galli G, Beltrame C, Romagnani P, Manetti R, Romagnani S, Maggi E: Assessment of chemokine receptor expression by human Th1 and Th2 cells in vitro and in vivo. J Leukoc Biol 1999, 65:691-699.

49. Heijink $\mid H$, Van Oosterhout AJ: Strategies for targeting T-cells in allergic diseases and asthma. Pharmacol Ther 2006, 112:489-500.

50. Kuhn CF, Bazin M, Philippe L, Zhang J, Tylaska L, Miret J, Bauer PH: Bipiperidinyl carboxylic acid amides as potent, selective, and functionally active CCR4 antagonists. Chem Biol Drug Des 2007, 70:268-272.

51. Vijayanand P, Durkin K, Hartmann G, Morjaria J, Seumois G, Staples KJ, Hall D, Bessant C, Bartholomew M, Howarth PH, et al: Chemokine receptor 4 plays a key role in T cell recruitment into the airways of asthmatic patients. J Immunol 2010, 184:4568-4574.

52. Woodfolk JA: T-cell responses to allergens. J Allergy Clin Immunol 2007, 119:280-294, quiz 295-286.

53. Panina-Bordignon $P$, Papi A, Mariani M, Di Lucia P, Casoni G, Bellettato C, Buonsanti C, Miotto D, Mapp C, Villa A, et al: The C-C chemokine receptors CCR4 and CCR8 identify airway T cells of allergen-challenged atopic asthmatics. J Clin Invest 2001, 107:1357-1364.

54. Chung CD, Kuo F, Kumer J, Motani AS, Lawrence CE, Henderson WR Jr, Venkataraman C: CCR8 is not essential for the development of inflammation in a mouse model of allergic airway disease. $J$ Immunol 2003, 170:581-587.

55. Mikhak Z, Fukui M, Farsidjani A, Medoff BD, Tager AM, Luster AD: Contribution of CCR4 and CCR8 to antigen-specific $T(H) 2$ cell trafficking in allergic pulmonary inflammation. J Allergy Clin Immunol 2009, 123:67-73, e63.

56. Fox JM, Najarro P, Smith GL, Struyf S, Proost P, Pease JE: Structure/function relationships of CCR8 agonists and antagonists. Amino-terminal extension of CCL1 by a single amino acid generates a partial agonist. J Biol Chem 2006, 281:36652-36661

57. Jin J, Wang Y, Wang F, Kerns JK, Vinader VM, Hancock AP, Lindon MJ, Stevenson Gl, Morrow DM, Rao P, et al: Oxazolidinones as novel human CCR8 antagonists. Bioorg Med Chem Lett 2007, 17:1722-1725.

58. Gonzalo JA, Lloyd CM, Peled A, Delaney T, Coyle AJ, Gutierrez-Ramos JC: Critical involvement of the chemotactic axis CXCR4/stromal cell-derived factor-1 alpha in the inflammatory component of allergic airway disease. $J$ Immunol 2000, 165:499-508.

59. Hu JS, Freeman CM, Stolberg VR, Chiu BC, Bridger GJ, Fricker SP, Lukacs NW, Chensue SW: AMD3465, a novel CXCR4 receptor antagonist, abrogates schistosomal antigen-elicited (type-2) pulmonary granuloma formation. Am J Pathol 2006, 169:424-432.

60. Lukacs NW, Berlin A, Schols D, Skerlj RT, Bridger GJ: AMD3100, a CxCR4 antagonist, attenuates allergic lung inflammation and airway hyperreactivity. Am J Pathol 2002, 160:1353-1360.

61. Humbles AA, Lu B, Friend DS, Okinaga S, Lora J, Al-Garawi A, Martin TR, Gerard NP, Gerard C: The murine CCR3 receptor regulates both the role of eosinophils and mast cells in allergen-induced airway inflammation and hyperresponsiveness. Proc Natl Acad Sci USA 2002, 99:1479-1484.

62. Sallusto F, Mackay CR, Lanzavecchia A: Selective expression of the eotaxin receptor CCR3 by human T helper 2 cells. Science 1997, 277:2005-2007.
63. Mori A, Ogawa K, Someya K, Kunori Y, Nagakubo D, Yoshie O, Kitamura F, Hiroi T, Kaminuma O: Selective suppression of Th2-mediated airway eosinophil infiltration by low-molecular weight CCR3 antagonists. Int Immunol 2007, 19:913-921.

64. Gauvreau GM, Boulet LP, Cockcroft DW, Baatjes A, Cote J, Deschesnes F, Davis B, Strinich T, Howie K, Duong M, et al: Antisense therapy against CCR3 and the common beta chain attenuates allergen-induced eosinophilic responses. Am J Respir Crit Care Med 2008, 177:952-958.

65. Kallinich T, Schmidt S, Hamelmann E, Fischer A, Qin S, Luttmann W, Virchow JC, Kroczek RA: Chemokine-receptor expression on T cells in lung compartments of challenged asthmatic patients. Clin Exp Allergy 2005, 35:26-33.

66. Thomas SY, Banerji A, Medoff BD, Lilly CM, Luster AD: Multiple chemokine receptors, including CCR6 and CXCR3, regulate antigen-induced T cell homing to the human asthmatic airway. J Immunol 2007, 179:1901-1912.

67. Mionnet C, Buatois V, Kanda A, Milcent V, Fleury S, Lair D, Langelot M Lacoeuille $Y$, Hessel $E$, Coffman $R$, et al: CX3CR1 is required for airway inflammation by promoting $T$ helper cell survival and maintenance in inflamed lung. Nat Med 2010, 16:1305-1312

68. Annunziato F, Cosmi L, Santarlasci V, Maggi L, Liotta F, Mazzinghi B, Parente E, Fili L, Ferri S, Frosali F, et al: Phenotypic and functional features of human Th17 cells. J Exp Med 2007, 204:1849-1861.

69. Pettipher $R$ : The roles of the prostaglandin $D(2)$ receptors $D P(1)$ and CRTH2 in promoting allergic responses. Br J Pharmacol 2008, 153(Suppl 1):S191-199.

70. Royer JF, Schratl P, Carrillo JJ, Jupp R, Barker J, Weyman-Jones C, Beri R, Sargent C, Schmidt JA, Lang-Loidolt D, Heinemann A: A novel antagonist of prostaglandin D2 blocks the locomotion of eosinophils and basophils. Eur J Clin Invest 2008, 38:663-671.

71. Lukacs NW, Berlin AA, Franz-Bacon K, Sasik R, Sprague LJ, Ly TW, Hardiman G, Boehme SA, Bacon KB: CRTH2 antagonism significantly ameliorates airway hyperreactivity and downregulates inflammationinduced genes in a mouse model of airway inflammation. Am J Physiol Lung Cell Mol Physiol 2008, 295:L767-779.

72. Stebbins KJ, Broadhead AR, Correa LD, Scott JM, Truong YP, Stearns BA, Hutchinson JH, Prasit P, Evans JF, Lorrain DS: Therapeutic efficacy of AM156, a novel prostanoid DP2 receptor antagonist, in murine models of allergic rhinitis and house dust mite-induced pulmonary inflammation. Eur J Pharmacol 2010, 638:142-149.

73. Torres D, Paget C, Fontaine J, Mallevaey T, Matsuoka T, Maruyama T, Narumiya S, Capron M, Gosset P, Faveeuw C, Trottein F: Prostaglandin D2 inhibits the production of IFN-gamma by invariant NK T cells: consequences in the control of B16 melanoma. J Immunol 2008, 180:783-792.

74. Schuligoi R, Sedej M, Waldhoer M, Vukoja A, Sturm EM, Lippe IT, Peskar BA, Heinemann A: Prostaglandin $\mathrm{H} 2$ induces the migration of human eosinophils through the chemoattractant receptor homologous molecule of Th2 cells, CRTH2. J Leukoc Biol 2009, 85:136-145.

75. Tajima T, Murata T, Aritake K, Urade $Y$, Hirai H, Nakamura M, Ozaki H, Hori M: Lipopolysaccharide induces macrophage migration via prostaglandin $\mathrm{D}(2)$ and prostaglandin $\mathrm{E}(2)$. J Pharmacol Exp Ther 2008, 326:493-501.

76. Porter JC, Hall A: Epithelial ICAM-1 and ICAM-2 regulate the egression of human T cells across the bronchial epithelium. Faseb J 2009, 23:492-502.

77. Furusho S, Myou S, Fujimura M, Kita T, Yasui M, Kasahara K, Nakao S, Takehara K, Sato S: Role of intercellular adhesion molecule-1 in a murine model of toluene diisocyanate-induced asthma. Clin Exp Allergy 2006, 36:1294-1302

78. Ueki S, Kihara J, Kato H, Ito W, Takeda M, Kobayashi Y, Kayaba H, Chihara J: Soluble vascular cell adhesion molecule-1 induces human eosinophil migration. Allergy 2009, 64:718-724.

79. Parmley LA, Elkins ND, Fini MA, Liu YE, Repine JE, Wright RM: Alpha-4/beta-1 and alpha-L/beta-2 integrins mediate cytokine induced lung leukocyteepithelial adhesion and injury. Br J Pharmacol 2007, 152:915-929.

80. Kelly M, Hwang JM, Kubes P: Modulating leukocyte recruitment in inflammation. J Allergy Clin Immunol 2007, 120:3-10.

81. Mackay CR: Moving targets: cell migration inhibitors as new antiinflammatory therapies. Nat Immunol 2008, 9:988-998.

82. Kenyon NJ, Liu R, O'Roark EM, Huang W, Peng L, Lam KS: An alpha4 beta1 integrin antagonist decreases airway inflammation in ovalbuminexposed mice. Eur J Pharmacol 2009, 603:138-146. 
83. Ravensberg AJ, Luijk B, Westers P, Hiemstra PS, Sterk PJ, Lammers JW, Rabe KF: The effect of a single inhaled dose of a VLA-4 antagonist on allergen-induced airway responses and airway inflammation in patients with asthma. Allergy 2006, 61:1097-1103.

84. Davenport RJ, Munday JR: Alpha4-integrin antagonism-an effective approach for the treatment of inflammatory diseases? Drug Discov Today 2007, 12:569-576.

85. Muro F, limura S, Yoneda Y, Chiba J, Watanabe T, Setoguchi M, Takayama G, Yokoyama M, Takashi T, Nakayama A, Machinaga N: A novel and potent VLA-4 antagonist based on trans-4-substituted cyclohexanecarboxylic acid. Bioorg Med Chem 2009, 17:1232-1243.

86. Saku O, Ohta K, Arai E, Nomoto Y, Miura H, Nakamura H, Fuse E, Nakasato Y: Synthetic study of VLA-4/VCAM-1 inhibitors: synthesis and structureactivity relationship of piperazinylphenylalanine derivatives. Bioorg Med Chem Lett 2008, 18:1053-1057.

87. Li JP, Vlodavsky I: Heparin, heparan sulfate and heparanase in inflammatory reactions. Thromb Haemost 2009, 102:823-828.

88. Duong M, Cockcroft D, Boulet LP, Ahmed T, Iverson H, Atkinson DC, Stahl EG, Watson R, Davis B, Milot J, et al: The effect of IVX-0142, a heparin-derived hypersulfated disaccharide, on the allergic airway responses in asthma. Allergy 2008, 63:1195-1201.

89. Spinozzi F, de Benedictis D, de Benedictis FM: Apoptosis, airway inflammation and anti-asthma therapy: from immunobiology to clinical application. Pediatr Allergy Immunol 2008, 19:287-295.

90. Simon HU: Cell death in allergic diseases. Apoptosis 2009, 14:439-446.

91. Ohkusu-Tsukada K, Tsukada T, Isobe K: Accelerated development and aging of the immune system in p53-deficient mice. J Immunol 1999, 163:1966-1972.

92. Lee KM, Chuang E, Griffin M, Khattri R, Hong DK, Zhang W, Straus D, Samelson LE, Thompson CB, Bluestone JA: Molecular basis of T cell inactivation by CTLA-4. Science 1998, 282:2263-2266.

93. da Rocha Dias S, Rudd CE: CTLA-4 blockade of antigen-induced cell death. Blood 2001, 97:1134-1137.

94. Ubaldi V, Gatta L, Pace L, Doria G, Pioli C: CTLA-4 engagement inhibits Th2 but not Th1 cell polarisation. Clin Dev Immunol 2003, 10:13-17.

95. Abdulamir AS, Hafidh RR, Abubakar F, Abbas KA: Changing survival, memory cell compartment, and T-helper balance of lymphocytes between severe and mild asthma. BMC Immunol 2008, 9:73.

96. Ramsdell F, Seaman MS, Miller RE, Picha KS, Kennedy MK, Lynch DH: Differential ability of Th1 and Th2 T cells to express Fas ligand and to undergo activation-induced cell death. Int Immunol 1994, 6:1545-1553.

97. Fang Y, Yu S, Ellis JS, Sharav T, Braley-Mullen H: Comparison of sensitivity of Th1, Th2, and Th17 cells to Fas-mediated apoptosis. J Leukoc Biol 2010, 87:1019-1028.

98. Tong J, Clay BS, Ferreira CM, Bandukwala HS, Moore TV, Blaine KM, Williams JW, Hoffman LM, Hamann KJ, Shilling RA, et al: Fas ligand expression on T Cells is sufficient to prevent prolonged airway inflammation in a murine model of asthma. Am J Respir Cell Mol Biol 2010, 43:342-348.

99. Wang $Y$, Bi $Y$, Wu K, Wang C: Dendritic cell co-transfected with FasL and allergen genes induces $T$ cell tolerance and decreases airway inflammation in allergen induced murine model. Mol Biol Rep 2011, 38:809-817.

100. Devadas S, Das J, Liu C, Zhang L, Roberts Al, Pan Z, Moore PA, Das G, Shi Y: Granzyme B is critical for T cell receptor-induced cell death of type 2 helper T cells. Immunity 2006, 25:237-247.

101. Hothersall E, McSharry C, Thomson NC: Potential therapeutic role for statins in respiratory disease. Thorax 2006, 61:729-734.

102. Robinson AJ, Kashanin D, O'Dowd F, Fitzgerald K, Williams V, Walsh GM: Fluvastatin and lovastatin inhibit granulocyte macrophage-colony stimulating factor-stimulated human eosinophil adhesion to intercellular adhesion molecule-1 under flow conditions. Clin Exp Allergy 2009, 39:1866-1874.

103. Kim DY, Ryu SY, Lim JE, Lee YS, Ro JY: Anti-inflammatory mechanism of simvastatin in mouse allergic asthma model. Eur J Pharmacol 2007, 557:76-86

104. Imamura M, Okunishi K, Ohtsu H, Nakagome K, Harada H, Tanaka R, Yamamoto K, Dohi M: Pravastatin attenuates allergic airway inflammation by suppressing antigen sensitisation, interleukin 17 production and antigen presentation in the lung. Thorax 2009, 64:44-49.
105. Chiba Y, Arima J, Sakai H, Misawa M: Lovastatin inhibits bronchial hyperresponsiveness by reducing RhoA signaling in rat allergic asthma. Am J Physiol Lung Cell Mol Physiol 2008, 294:L705-713.

106. Zhou Q, Liao JK: Rho kinase: an important mediator of atherosclerosis and vascular disease. Curr Pharm Des 2009, 15:3108-3115.

107. Schaafsma D, Gosens R, Zaagsma J, Halayko AJ, Meurs H: Rho kinase inhibitors: a novel therapeutical intervention in asthma? Eur J Pharmacol 2008, 585:398-406.

108. Aihara M, Dobashi K, lizuka K, Nakazawa T, Mori M: Effect of Y-27632 on release of cytokines from peripheral $T$ cells in asthmatic patients and normal subjects. Int Immunopharmacol 2004, 4:557-561.

109. Lin J, Kane LP: Are TIM proteins involved in asthma development or pathology? Clinical and experimental allergy: journal of the British Society for Allergy and Clinical Immunology 2011, 41:917-919.

110. Su EW, Lin JY, Kane LP: TIM-1 and TIM-3 proteins in immune regulation. Cytokine 2008, 44:9-13.

111. Kuchroo VK, Dardalhon V, Xiao S, Anderson AC: New roles for TIM family members in immune regulation. Nat Rev Immunol 2008, 8:577-580.

112. Grigorian A, Torossian S, Demetriou M: T-cell growth, cell surface organization, and the galectin-glycoprotein lattice. Immunol Rev 2009, 230:232-246

113. Ge XN, Bahaie NS, Kang BN, Hosseinkhani MR, Ha SG, Frenzel EM, Liu FT, Rao SP, Sriramarao P: Allergen-induced airway remodeling is impaired in galectin-3-deficient mice. J Immunol 2010, 185:1205-1214.

114. Lopez E, del Pozo V, Miguel T, Sastre B, Seoane C, Civantos E, Llanes E, Baeza ML, Palomino P, Cardaba B, et al: Inhibition of chronic airway inflammation and remodeling by galectin-3 gene therapy in a murine model. J Immunol 2006, 176:1943-1950.

115. Katoh S, Ishii N, Nobumoto A, Takeshita K, Dai SY, Shinonaga R, Niki T, Nishi N, Tominaga A, Yamauchi A, Hirashima M: Galectin-9 inhibits CD44hyaluronan interaction and suppresses a murine model of allergic asthma. Am J Respir Crit Care Med 2007, 176:27-35.

116. Varki A, Angata T: Siglecs-the major subfamily of I-type lectins. Glycobiology 2006, 16:1R-27R.

117. Angata T, Margulies EH, Green ED, Varki A: Large-scale sequencing of the CD33-related Siglec gene cluster in five mammalian species reveals rapid evolution by multiple mechanisms. Proceedings of the National Academy of Sciences of the United States of America 2004, 101:13251-13256.

118. Zhang M, Angata T, Cho JY, Miller M, Broide DH, Varki A: Defining the in vivo function of Siglec-F, a CD33-related Siglec expressed on mouse eosinophils. Blood 2007, 109:4280-4287.

119. Song DJ, Cho JY, Lee SY, Miller M, Rosenthal P, Soroosh P, Croft M, Zhang $M$, Varki A, Broide DH: Anti-Siglec-F antibody reduces allergeninduced eosinophilic inflammation and airway remodeling. Journal of immunology 2009, 183:5333-5341.

120. Nguyen DH, Hurtado-Ziola N, Gagneux P, Varki A: Loss of Siglec expression on T lymphocytes during human evolution. Proceedings of the National Academy of Sciences of the United States of America 2006, 103:7765-7770.

121. King NE, Rothenberg ME, Zimmermann N: Arginine in asthma and lung inflammation. J Nutr 2004, 134:2830S-2836S, discussion 2853S.

122. Maarsingh $\mathrm{H}$, Zaagsma J, Meurs H: Arginase: a key enzyme in the pathophysiology of allergic asthma opening novel therapeutic perspectives. Br J Pharmacol 2009, 158:652-664.

123. Zimmermann N, King NE, Laporte J, Yang M, Mishra A, Pope SM, Muntel EE, Witte DP, Pegg AA, Foster PS, et al: Dissection of experimental asthma with DNA microarray analysis identifies arginase in asthma pathogenesis. J Clin Invest 2003, 111:1863-1874.

124. Yang $M$, Rangasamy D, Matthaei Kl, Frew AJ, Zimmmermann N, Mahalingam S, Webb DC, Tremethick DJ, Thompson PJ, Hogan SP, et al: Inhibition of arginase I activity by RNA interference attenuates IL-13induced airways hyperresponsiveness. J Immunol 2006, 177:5595-5603.

125. Pesce JT, Ramalingam TR, Mentink-Kane MM, Wilson MS, El Kasmi KC, Smith AM, Thompson RW, Cheever AW, Murray PJ, Wynn TA: Arginase-1expressing macrophages suppress Th2 cytokine-driven inflammation and fibrosis. PLOS Pathog 2009, 5:e1000371.

126. Su RC, Becker AB, Kozyrskyj AL, Hayglass KT: Epigenetic regulation of established human type 1 versus type 2 cytokine responses. J Allergy Clin Immunol 2008, 121:57-63, e53.

127. Choi JH, Oh SW, Kang MS, Kwon HJ, Oh GT, Kim DY: Trichostatin A attenuates airway inflammation in mouse asthma model. Clin Exp Allergy 2005, 35:89-96. 
128. Grausenburger R, Bilic I, Boucheron N, Zupkovitz G, El-Housseiny L, Tschismarov R, Zhang Y, Rembold M, Gaisberger M, Hartl A, et al: Conditional deletion of histone deacetylase 1 in T cells leads to enhanced airway inflammation and increased Th2 cytokine production. J Immunol 2010, 185:3489-3497.

129. Debarry J, Garn H, Hanuszkiewicz A, Dickgreber N, Blumer N, von Mutius E, Bufe A, Gatermann S, Renz H, Holst O, Heine H: Acinetobacter Iwoffii and Lactococcus lactis strains isolated from farm cowsheds possess strong allergy-protective properties. J Allergy Clin Immunol 2007, 119:1514-1521.

130. Smit JJ, Folkerts G, Nijkamp FP: Mycobacteria, genes and the 'hygiene hypothesis'. Curr Opin Allergy Clin Immunol 2004, 4:57-62.

131. Christ AP, Rodriguez D, Bortolatto J, Borducchi E, Keller A, Mucida D, Silva JS, Leite LC, Russo M: Enhancement of Th1 Lung Immunity Induced by Recombinant Mycobacterium bovis BCG Attenuates Airway Allergic Disease. Am J Respir Cell Mol Biol 2009.

132. Yokoi T, Amakawa R, Tanijiri T, Sugimoto H, Torii $Y$, Amuro $H$, Son $Y$, Tajima K, Liu YJ, Ito T, Fukuhara S: Mycobacterium bovis Bacillus CalmetteGuerin suppresses inflammatory Th2 responses by inducing functional alteration of TSLP-activated dendritic cells. Int Immunol 2008, 20:1321-1329.

133. Ou-Yang HF, Hu XB, Ti XY, Shi JR, Li SJ, Qi HW, Wu CG: Suppression of allergic airway inflammation in a mouse model by Der p2 recombined BCG. Immunology 2009, 128:e343-352.

134. Wu Q, Martin RJ, Lafasto S, Chu HW: A low dose of Mycoplasma pneumoniae infection enhances an established allergic inflammation in mice: the role of the prostaglandin E2 pathway. Clin Exp Allergy 2009, 39:1754-1763.

135. Delayre-Orthez C, de Blay F, Frossard N, Pons F: Dose-dependent effects of endotoxins on allergen sensitization and challenge in the mouse. Clin Exp Allergy 2004, 34:1789-1795.

136. Ichikawa S, Takai T, Yashiki T, Takahashi S, Okumura K, Ogawa H, Kohda D, Hatanaka H: Lipopolysaccharide binding of the mite allergen Der $\mathrm{f} 2$. Genes Cells 2009, 14:1055-1065.

137. Inohara N, Nunez G: ML - a conserved domain involved in innate immunity and lipid metabolism. Trends Biochem Sci 2002, 27:219-221.

138. Klinman D, Shirota $H$, Tross D, Sato $T$, Klaschik S: Synthetic oligonucleotides as modulators of inflammation. J Leukoc Biol 2008, 84:958-964.

139. Fonseca DE, Kline JN: Use of CpG oligonucleotides in treatment of asthma and allergic disease. Adv Drug Deliv Rev 2009, 61:256-262.

140. Sur S, Wild JS, Choudhury BK, Sur N, Alam R, Klinman DM: Long term prevention of allergic lung inflammation in a mouse model of asthma by CpG oligodeoxynucleotides. J Immunol 1999, 162:6284-6293.

141. Constabel H, Stankov MV, Hartwig C, Tschernig T, Behrens GM: Impaired lung dendritic cell migration and $\mathrm{T}$ cell stimulation induced by immunostimulatory oligonucleotides contribute to reduced allergic airway inflammation. J Immunol 2009, 183:3443-3453.

142. Hessel EM, Chu M, Lizcano JO, Chang B, Herman N, Kell SA, Wills-Karp M, Coffman RL: Immunostimulatory oligonucleotides block allergic airway inflammation by inhibiting Th2 cell activation and lgE-mediated cytokine induction. J Exp Med 2005, 202:1563-1573.

143. Senti G, Johansen P, Haug S, Bull C, Gottschaller C, Muller P, Pfister T, Maurer P, Bachmann MF, Graf N, Kundig TM: Use of A-type CpG oligodeoxynucleotides as an adjuvant in allergen-specific immunotherapy in humans: a phase I/Ila clinical trial. Clin Exp Allergy 2009, 39:562-570.

144. Angeli V, Hammad H, Staels B, Capron M, Lambrecht BN, Trottein F: Peroxisome proliferator-activated receptor gamma inhibits the migration of dendritic cells: consequences for the immune response. J Immunol 2003, 170:5295-5301.

145. Hammad H, de Heer HJ, Soullie T, Angeli V, Trottein F, Hoogsteden HC, Lambrecht BN: Activation of peroxisome proliferator-activated receptorgamma in dendritic cells inhibits the development of eosinophilic airway inflammation in a mouse model of asthma. Am J Pathol 2004, 164:263-271.

146. Hutchison S, Choo-Kang BS, Gibson VB, Bundick RV, Leishman AJ, Brewer JM, Mclnnes IB, Garside P: An investigation of the impact of the location and timing of antigen-specific $T$ cell division on airways inflammation. Clin Exp Immunol 2009, 155:107-116

147. Idzko M, Hammad $H$, van Nimwegen M, Kool M, Muller T, Soullie T, Willart MA, Hijdra D, Hoogsteden HC, Lambrecht BN: Local application of
FTY720 to the lung abrogates experimental asthma by altering dendritic cell function. J Clin Invest 2006, 116:2935-2944.

148. Nishiuma T, Nishimura Y, Okada T, Kuramoto E, Kotani Y, Jahangeer S, Nakamura S: Inhalation of sphingosine kinase inhibitor attenuates airway inflammation in asthmatic mouse model. Am J Physiol Lung Cell Mol Physiol 2008, 294:L1085-1093.

149. Sawicka E, Zuany-Amorim C, Manlius C, Trifilieff A, Brinkmann V, Kemeny DM, Walker C: Inhibition of Th1- and Th2-mediated airway inflammation by the sphingosine 1-phosphate receptor agonist FTY720. J Immunol 2003, 171:6206-6214.

150. Xia M, Sui Z: Recent developments in CCR2 antagonists. Expert Opin Ther Pat 2009, 19:295-303

151. Pichavant M, Charbonnier AS, Taront S, Brichet A, Wallaert B, Pestel J, Tonnel AB, Gosset P: Asthmatic bronchial epithelium activated by the proteolytic allergen Der $\mathrm{p} 1$ increases selective dendritic cell recruitment. J Allergy Clin Immunol 2005, 115:771-778.

152. Ip WK, Wong CK, Lam CW: Interleukin (IL)-4 and IL-13 up-regulate monocyte chemoattractant protein-1 expression in human bronchial epithelial cells: involvement of p38 mitogen-activated protein kinase, extracellular signal-regulated kinase $1 / 2$ and Janus kinase-2 but not cJun NH2-terminal kinase 1/2 signalling pathways. Clin Exp Immunol 2006, 145:162-172.

153. Hammad H, Kool M, Soullie T, Narumiya S, Trottein F, Hoogsteden HC, Lambrecht BN: Activation of the $D$ prostanoid 1 receptor suppresses asthma by modulation of lung dendritic cell function and induction of regulatory T cells. J Exp Med 2007, 204:357-367.

154. Crosby JR, Guha M, Tung D, Miller DA, Bender B, Condon TP, YorkDeFalco C, Geary RS, Monia BP, Karras JG, Gregory SA: Inhaled CD86 antisense oligonucleotide suppresses pulmonary inflammation and airway hyper-responsiveness in allergic mice. J Pharmacol Exp Ther 2007, 321:938-946

155. Yokomura K, Suda T, Matsuda H, Hashizume H, Asada K, Suzuki K, Chida K: Suplatast tosilate alters DC1/DC2 balance in peripheral blood in bronchial asthma. J Asthma 2005, 42:567-570.

156. Chen YQ, Shi HZ: CD28/CTLA-4-CD80/CD86 and ICOS-B7RP-1 costimulatory pathway in bronchial asthma. Allergy 2006, 61:15-26.

157. Seshasayee D, Lee WP, Zhou M, Shu J, Suto E, Zhang J, Diehl L, Austin CD, Meng YG, Tan M, et al: In vivo blockade of OX40 ligand inhibits thymic stromal lymphopoietin driven atopic inflammation. J Clin Invest 2007, 117:3868-3878.

158. Singh AK, Stock P, Akbari O: Role of PD-L1 and PD-L2 in allergic diseases and asthma. Allergy 2011, 66:155-162.

159. Tilley SL, Boucher RC: A1 antagonism in asthma: better than coffee? J Clin Invest 2005, 115:13-16.

160. Lopez-Castejon G, Baroja-Mazo A, Pelegrin P: Novel macrophage polarization model: from gene expression to identification of new antiinflammatory molecules. Cell Mol Life Sci 2010.

161. Chen CL, Wang YM, Liu CF, Wang JY: The effect of water-soluble chitosan on macrophage activation and the attenuation of mite allergen-induced airway inflammation. Biomaterials 2008, 29:2173-2182.

162. Korf JE, Pynaert G, Tournoy K, Boonefaes T, Van Oosterhout $A$ Ginneberge D, Haegeman A, Verschoor JA, De Baetselier P, Grooten J: Macrophage reprogramming by mycolic acid promotes a tolerogenic response in experimental asthma. Am J Respir Crit Care Med 2006, 174:152-160

163. Perrigoue JG, Saenz SA, Siracusa MC, Allenspach EJ, Taylor BC, Giacomin PR, Nair MG, Du Y, Zaph C, van Rooijen N, et al: MHC class II-dependent basophil-CD4+ T cell interactions promote $\mathrm{T}(\mathrm{H}) 2$ cytokine-dependent immunity. Nat Immunol 2009, 10:697-705.

164. Sokol CL, Barton GM, Farr AG, Medzhitov R: A mechanism for the initiation of allergen-induced T helper type 2 responses. Nat Immunol 2008, 9:310-318

165. Sokol CL, Chu NQ, Yu S, Nish SA, Laufer TM, Medzhitov R: Basophils function as antigen-presenting cells for an allergen-induced T helper type 2 response. Nat Immunol 2009, 10:713-720.

166. Yoshimoto T, Yasuda K, Tanaka H, Nakahira M, Imai Y, Fujimori Y, Nakanishi K: Basophils contribute to $\mathrm{T}(\mathrm{H}) 2-\mathrm{IgE}$ responses in vivo via IL-4 production and presentation of peptide-MHC class II complexes to CD4 + T cells. Nat Immunol 2009, 10:706-712.

167. Hammad H, Plantinga M, Deswarte $K$, Pouliot $P$, Willart MA, Kool M, Muskens F, Lambrecht BN: Inflammatory dendritic cells-not basophils-are 
necessary and sufficient for induction of Th2 immunity to inhaled house dust mite allergen. J Exp Med 2010, 207:2097-2111.

168. Kim S, Prout M, Ramshaw H, Lopez AF, LeGros G, Min B: Cutting edge: basophils are transiently recruited into the draining lymph nodes during helminth infection via IL-3, but infection-induced Th2 immunity can develop without basophil lymph node recruitment or IL-3. Journal of immunology 2010, 184:1143-1147.

169. Ho IC, Tai TS, Pai SY: GATA3 and the T-cell lineage: essential functions before and after T-helper-2-cell differentiation. Nat Rev Immunol 2009, 9:125-135

170. Finotto S, De Sanctis GT, Lehr HA, Herz U, Buerke M, Schipp M, Bartsch B, Atreya R, Schmitt E, Galle PR, et al: Treatment of allergic airway inflammation and hyperresponsiveness by antisense-induced local blockade of GATA-3 expression. J Exp Med 2001, 193:1247-1260.

171. Lee CC, Huang HY, Chiang BL: Lentiviral-mediated GATA-3 RNAi decreases allergic airway inflammation and hyperresponsiveness. $\mathrm{Mol}$ Ther 2008, 16:60-65.

172. Stritesky GL, Muthukrishnan R, Sehra S, Goswami R, Pham D, Travers J, Nguyen ET, Levy DE, Kaplan MH: The transcription factor STAT3 is required for T helper 2 cell development. Immunity 2011, 34:39-49.

173. Simeone-Penney MC, Severgnini M, Tu P, Homer RJ, Mariani TJ, Cohn L, Simon AR: Airway epithelial STAT3 is required for allergic inflammation in a murine model of asthma. J Immunol 2007, 178:6191-6199.

174. Kagami S, Nakajima H, Kumano K, Suzuki K, Suto A, Imada K, Davey HW, Saito Y, Takatsu K, Leonard WJ, Iwamoto I: Both stat5a and stat5b are required for antigen-induced eosinophil and T-cell recruitment into the tissue. Blood 2000, 95:1370-1377.

175. D'Cruz LM, Klein L: Development and function of agonist-induced CD25 + Foxp3+ regulatory T cells in the absence of interleukin 2 signaling. Nat Immunol 2005, 6:1152-1159.

176. Ohga K, Kuromitsu S, Takezawa R, Numazaki M, Ishikawa J, Nagashima S, Shimizu Y: YM-341619 suppresses the differentiation of spleen T cells into Th2 cells in vitro, eosinophilia, and airway hyperresponsiveness in rat allergic models. Eur J Pharmacol 2008, 590:409-416.

177. Walker W, Healey GD, Hopkin JM: RNA interference of STAT6 rapidly attenuates ongoing interleukin-13-mediated events in lung epithelial cells. Immunology 2009, 127:256-266.

178. Amsen D, Antov A, Jankovic D, Sher A, Radtke F, Souabni A, Busslinger M, McCright B, Gridley T, Flavell RA: Direct regulation of Gata3 expression determines the T helper differentiation potential of Notch. Immunity 2007, 27:89-99.

179. Fang TC, Yashiro-Ohtani Y, Del Bianco C, Knoblock DM, Blacklow SC, Pear WS: Notch directly regulates Gata3 expression during T helper 2 cell differentiation. Immunity 2007, 27:100-110.

180. Kang JH, Kim BS, Uhm TG, Lee SH, Lee GR, Park CS, Chung IY: Gammasecretase inhibitor reduces allergic pulmonary inflammation by modulating Th1 and Th2 responses. Am J Respir Crit Care Med 2009, 179:875-882.

181. Tu L, Fang TC, Artis D, Shestova O, Pross SE, Maillard I, Pear WS: Notch signaling is an important regulator of type 2 immunity. J Exp Med 2005, 202:1037-1042.

182. Kovall RA: More complicated than it looks: assembly of Notch pathway transcription complexes. Oncogene 2008, 27:5099-5109.

183. Fortini ME: Notch signaling: the core pathway and its posttranslational regulation. Dev Cell 2009, 16:633-647.

184. Ho IC, Hodge MR, Rooney JW, Glimcher LH: The proto-oncogene c-maf is responsible for tissue-specific expression of interleukin-4. Cell 1996, 85:973-983.

185. Ho IC, Lo D, Glimcher LH: c-maf promotes T helper cell type 2 (Th2) and attenuates Th1 differentiation by both interleukin 4-dependent and -independent mechanisms. J Exp Med 1998, 188:1859-1866.

186. Ko E, Rho S, Cho C, Choi H, Ko S, Lee Y, Hong MC, Shin MK, Jung SG, Bae H: So-Cheong-Ryong-Tang, tradititional Korean medicine, suppresses Th2 lineage development. Biol Pharm Bull 2004, 27:739-743.

187. Won HY, Min HJ, Ahn JH, Yoo SE, Bae MA, Hong JH, Hwang ES: Antiallergic function and regulatory mechanisms of KR62980 in allergeninduced airway inflammation. Biochem Pharmacol 2009.

188. Liu Z, Li Z, Mao K, Zou J, Wang Y, Tao Z, Lin G, Tian L, Ji Y, Wu X, et al: Dec2 promotes Th2 cell differentiation by enhancing IL-2R signaling. $J$ Immunol 2009, 183:6320-6329.
189. Yang XO, Angkasekwinai P, Zhu J, Peng J, Liu Z, Nurieva R, Liu X, Chung Y, Chang SH, Sun B, Dong C: Requirement for the basic helix-loop-helix transcription factor Dec2 in initial TH2 lineage commitment. Nat Immunol 2009, 10:1260-1266.

190. Shinnakasu R, Yamashita M, Kuwahara M, Hosokawa H, Hasegawa A Motohashi S, Nakayama T: Gfi1-mediated stabilization of GATA3 protein is required for Th2 cell differentiation. J Biol Chem 2008, 283:28216-28225.

191. Hirahara K, Yamashita M, Iwamura C, Shinoda K, Hasegawa A, Yoshizawa H, Koseki H, Gejyo F, Nakayama T: Repressor of GATA regulates TH2-driven allergic airway inflammation and airway hyperresponsiveness. J Allergy Clin Immunol 2008, 122:512-520, e511.

192. Kusam S, Toney LM, Sato H, Dent AL: Inhibition of Th2 differentiation and GATA-3 expression by BCL-6. J Immunol 2003, 170:2435-2441.

193. Yoshimura A, Naka T, Kubo M: SOCS proteins, cytokine signalling and immune regulation. Nat Rev Immunol 2007, 7:454-465.

194. Seki Y, Inoue H, Nagata N, Hayashi K, Fukuyama S, Matsumoto K, Komine O, Hamano S, Himeno K, Inagaki-Ohara K, et al: SOCS-3 regulates onset and maintenance of $\mathrm{T}(\mathrm{H}) 2$-mediated allergic responses. Nat Med 2003, 9:1047-1054

195. Taleb S, Romain M, Ramkhelawon B, Uyttenhove C, Pasterkamp G Herbin O, Esposito B, Perez N, Yasukawa H, Van Snick J, et al: Loss of SOCS3 expression in T cells reveals a regulatory role for interleukin-17 in atherosclerosis. J Exp Med 2009, 206:2067-2077.

196. Seki Y, Hayashi K, Matsumoto A, Seki N, Tsukada J, Ransom J, Naka T, Kishimoto T, Yoshimura A, Kubo M: Expression of the suppressor of cytokine signaling-5 (SOCS5) negatively regulates IL-4-dependent STAT6 activation and Th2 differentiation. Proc Natl Acad Sci USA 2002, 99:13003-13008.

197. Ohshima M, Yokoyama A, Ohnishi H, Hamada H, Kohno N, Higaki J, Naka T: Overexpression of suppressor of cytokine signalling- 5 augments eosinophilic airway inflammation in mice. Clin Exp Allergy 2007, 37:735-742.

198. Lu TX, Munitz A, Rothenberg ME: MicroRNA-21 is up-regulated in allergic airway inflammation and regulates IL-12p35 expression. J Immunol 2009, 182:4994-5002.

199. Mattes J, Collison A, Plank M, Phipps S, Foster PS: Antagonism of microRNA-126 suppresses the effector function of TH2 cells and the development of allergic airways disease. Proc Natl Acad Sci USA 2009, 106:18704-18709.

200. Hur GY, Lee SY, Lee SH, Kim SJ, Lee KJ, Jung JY, Lee EJ, Kang EH, Jung KH, $\mathrm{Kim} \mathrm{JH}$, et al: Potential use of an anticancer drug gefinitib, an EGFR inhibitor, on allergic airway inflammation. Exp Mol Med 2007, 39:367-375.

201. Yamamoto N, Takeshita K, Shichijo M, Kokubo T, Sato M, Nakashima K, Ishimori M, Nagai H, Li YF, Yura T, Bacon KB: The orally available spleen tyrosine kinase inhibitor 2-[7-(3,4-dimethoxyphenyl)-imidazo[1,2-c] pyrimidin-5-ylamino]nicotinamide dihydrochloride (BAY 61-3606) blocks antigen-induced airway inflammation in rodents. J Pharmacol Exp Ther 2003, 306:1174-1181.

202. Meltzer EO, Berkowitz RB, Grossbard EB: An intranasal Syk-kinase inhibitor (R112) improves the symptoms of seasonal allergic rhinitis in a park environment. J Allergy Clin Immunol 2005, 115:791-796.

203. Kudlacz E, Conklyn M, Andresen C, Whitney-Pickett C, Changelian P: The JAK-3 inhibitor CP-690550 is a potent anti-inflammatory agent in a murine model of pulmonary eosinophilia. Eur J Pharmacol 2008 , 582:154-161.

204. Malaviya R, Chen CL, Navara C, Liu XP, Keenan M, Waurzyniak B, Uckun FM: Treatment of allergic asthma by targeting janus kinase 3-dependent leukotriene synthesis in mast cells with 4-(3', 5'-dibromo-4'hydroxyphenyl)amino-6,7-dimethoxyquinazoline (WHI-P97). J Pharmacol Exp Ther 2000, 295:912-926.

205. Malaviya R, Zhu D, Dibirdik I, Uckun FM: Targeting Janus kinase 3 in mast cells prevents immediate hypersensitivity reactions and anaphylaxis. J Biol Chem 1999, 274:27028-27038.

206. Duan W, Chan JH, Wong CH, Leung BP, Wong WS: Anti-inflammatory effects of mitogen-activated protein kinase kinase inhibitor U0126 in an asthma mouse model. J Immunol 2004, 172:7053-7059.

207. Duan W, Chan JH, McKay K, Crosby JR, Choo HH, Leung BP, Karras JG, Wong WS: Inhaled p38 alpha mitogen-activated protein kinase antisense oligonucleotide attenuates asthma in mice. Am J Respir Crit Care Med 2005, 171:571-578. 
208. Adcock IM, Chung KF, Caramori G, Ito K: Kinase inhibitors and airway inflammation. Eur J Pharmacol 2006, 533:118-132.

209. Barnes PJ: Novel signal transduction modulators for the treatment of airway diseases. Pharmacol Ther 2006, 109:238-245.

210. Gruenbaum LM, Schwartz R, Woska JR Jr, DeLeon RP, Peet GW, Warren TC Capolino A, Mara L, Morelock MM, Shrutkowski A, et al: Inhibition of proinflammatory cytokine production by the dual p38/JNK2 inhibitor BIRB796 correlates with the inhibition of p38 signaling. Biochem Pharmacol 2009, 77:422-432.

211. Chialda L, Zhang M, Brune K, Pahl A: Inhibitors of mitogen-activated protein kinases differentially regulate costimulated $T$ cell cytokine production and mouse airway eosinophilia. Respir Res 2005, 6:36.

212. Nath P, Eynott P, Leung SY, Adcock IM, Bennett BL, Chung KF: Potential role of c-Jun $\mathrm{NH}$ 2-terminal kinase in allergic airway inflammation and remodelling: effects of SP600125. Eur J Pharmacol 2005, 506:273-283.

213. Trifilieff A, Keller TH, Press NJ, Howe T, Gedeck P, Beer D, Walker C: CGH2466, a combined adenosine receptor antagonist, p38 mitogenactivated protein kinase and phosphodiesterase type 4 inhibitor with potent in vitro and in vivo anti-inflammatory activities. $\mathrm{Br} J$ Pharmacol 2005, 144:1002-1010.

214. Lee KS, Park SJ, Kim SR, Min KH, Lee KY, Choe YH, Hong SH, Lee YR, Kim JS, Hong SJ, Lee YC: Inhibition of VEGF blocks TGF-beta1 production through a PI3K/Akt signalling pathway. Eur Respir J 2008, 31:523-531.

215. Park SJ, Min KH, Lee YC: Phosphoinositide 3-kinase delta inhibitor as a novel therapeutic agent in asthma. Respirology 2008, 13:764-771.

216. Birrell MA, Hardaker E, Wong S, McCluskie K, Catley M, De Alba J, Newton R, Haj-Yahia S, Pun KT, Watts CJ, et al: Ikappa-B kinase-2 inhibitor blocks inflammation in human airway smooth muscle and a rat model of asthma. Am J Respir Crit Care Med 2005, 172:962-971.

217. Ziegelbauer K, Gantner F, Lukacs NW, Berlin A, Fuchikami K, Niki T, Sakai K, Inbe $H$, Takeshita $K$, Ishimori $M$, et al: A selective novel low-molecularweight inhibitor of IkappaB kinase-beta (IKK-beta) prevents pulmonary inflammation and shows broad anti-inflammatory activity. Br J Pharmacol 2005, 145:178-192.

218. Hirose K, Wakashin H, Oki M, Kagami S, Suto A, Ikeda K, Watanabe N, Iwamoto I, Furuichi Y, Nakajima H: GS143, an IkappaB ubiquitination inhibitor, inhibits allergic airway inflammation in mice. Biochem Biophys Res Commun 2008, 374:507-511.

219. Lu S, Liu N, Dass SB, Reiss TF, Knorr BA: Randomized, placebo-controlled study of a selective PDE4 inhibitor in the treatment of asthma. Respir Med 2009, 103:342-347.

220. Singh D, Petavy F, Macdonald AJ, Lazaar AL, O'Connor BJ: The inhaled phosphodiesterase 4 inhibitor GSK256066 reduces allergen challenge responses in asthma. Respir Res 2010, 11:26.

221. Boswell-Smith V, Spina D, Oxford AW, Comer MB, Seeds EA, Page CP: The pharmacology of two novel long-acting phosphodiesterase 3/4 inhibitors, RPL554 [9,10-dimethoxy-2(2,4,6-trimethylphenylimino)-3-(ncarbamoyl-2-aminoethyl) -3,4,6,7-tetrahydro-2H-pyrimido[6,1-a] isoquinolin-4-one] and RPL565 [6,7-dihydro-2-(2,6-diisopropylphenoxy)9,10-dimethoxy-4H-pyrimido[6,1-a]i soquinolin-4-one]. J Pharmacol Exp Ther 2006, 318:840-848.

222. Hoyer KK, Dooms H, Barron L, Abbas AK: Interleukin-2 in the development and control of inflammatory disease. Immunol Rev 2008, 226:19-28.

223. Rothenberg ME, Owen WF Jr, Silberstein DS, Woods J, Soberman RJ, Austen KF, Stevens RL: Human eosinophils have prolonged survival, enhanced functional properties, and become hypodense when exposed to human interleukin 3. The Journal of clinical investigation 1988, 81:1986-1992.

224. Valent $P$, Dahinden $C A$ : Role of interleukins in the regulation of basophil development and secretion. Current opinion in hematology 2010, 17:60-66.

225. Asquith KL, Ramshaw HS, Hansbro PM, Beagley KW, Lopez AF, Foster PS: The IL-3/IL-5/GM-CSF common receptor plays a pivotal role in the regulation of Th2 immunity and allergic airway inflammation. J Immunol 2008, 180:1199-1206.

226. Webb DC, Cai Y, Matthaei KI, Foster PS: Comparative roles of IL-4, IL-13, and IL-4Ralpha in dendritic cell maturation and CD4+ Th2 cell function. J Immunol 2007, 178:219-227.

227. Corren J, Busse W, Meltzer EO, Mansfield L, Bensch G, Fahrenholz J, Wenzel SE, Chon Y, Dunn M, Weng HH, Lin SL: A randomized, controlled, phase 2 study of AMG 317, an IL-4Ralpha antagonist, in patients with asthma. American journal of respiratory and critical care medicine 2010 181:788-796.

228. Wenzel S, Wilbraham D, Fuller R, Getz EB, Longphre M: Effect of an interleukin- 4 variant on late phase asthmatic response to allergen challenge in asthmatic patients: results of two phase $2 a$ studies. Lancet 2007, 370:1422-1431.

229. Oh CK, Geba GP, Molfino N: Investigational therapeutics targeting the IL4/IL-13/STAT-6 pathway for the treatment of asthma. European respiratory review: an official journal of the European Respiratory Society 2010, 19:46-54.

230. Leckie MJ: Anti-interleukin-5 monoclonal antibodies: preclinical and clinical evidence in asthma models. Am J Respir Med 2003, 2:245-259.

231. Leckie MJ, ten Brinke A, Khan J, Diamant Z, O'Connor BJ, Walls CM, Mathur AK, Cowley HC, Chung KF, Djukanovic R, et al: Effects of an interleukin-5 blocking monoclonal antibody on eosinophils, airway hyper-responsiveness, and the late asthmatic response. Lancet 2000, 356:2144-2148.

232. Busse WW, Katial R, Gossage D, Sari S, Wang B, Kolbeck R, Coyle AJ, Koike M, Spitalny GL, Kiener PA, et al: Safety profile, pharmacokinetics, and biologic activity of MEDI-563, an anti-IL-5 receptor alpha antibody, in a phase I study of subjects with mild asthma. J Allergy Clin Immunol 2010, 125:1237-1244, e1232.

233. Haldar P, Brightling CE, Hargadon B, Gupta S, Monteiro W, Sousa A, Marshall RP, Bradding P, Green RH, Wardlaw AJ, Pavord ID: Mepolizumab and exacerbations of refractory eosinophilic asthma. The New England journal of medicine 2009, 360:973-984.

234. Nair P, Pizzichini MM, Kjarsgaard M, Inman MD, Efthimiadis A, Pizzichini E, Hargreave FE, O'Byrne PM: Mepolizumab for prednisone-dependent asthma with sputum eosinophilia. N Engl J Med 2009, 360:985-993.

235. Rincon M, Anguita J, Nakamura T, Fikrig E, Flavell RA: Interleukin (IL)-6 directs the differentiation of IL-4-producing CD4+ T cells. J Exp Med 1997, 185:461-469.

236. Mucida D, Salek-Ardakani S: Regulation of TH17 cells in the mucosal surfaces. J Allergy Clin Immunol 2009, 123:997-1003.

237. Weissenbach M, Clahsen T, Weber C, Spitzer D, Wirth D, Vestweber D, Heinrich PC, Schaper F: Interleukin- 6 is a direct mediator of T cell migration. Eur J Immunol 2004, 34:2895-2906.

238. Renauld JC, Goethals A, Houssiau F, Merz H, Van Roost E, Van Snick J: Human P40/IL-9. Expression in activated CD4+ T cells, genomic organization, and comparison with the mouse gene. J Immunol 1990, 144:4235-4241.

239. McLane MP, Haczku A, van de Rijn M, Weiss C, Ferrante V, MacDonald D, Renauld JC, Nicolaides NC, Holroyd K, Levitt RC: Interleukin-9 promotes allergen-induced eosinophilic inflammation and airway hyperresponsiveness in transgenic mice. Am J Respir Cell Mol Biol 1998, 19:713-720.

240. Temann UA, Geba GP, Rankin JA, Flavell RA: Expression of interleukin 9 in the lungs of transgenic mice causes airway inflammation, mast cell hyperplasia, and bronchial hyperresponsiveness. J Exp Med 1998, 188:1307-1320.

241. White B, Leon F, White W, Robbie G: Two first-in-human, open-label, phase I dose-escalation safety trials of MEDI-528, a monoclonal antibody against interleukin-9, in healthy adult volunteers. Clin Ther 2009, 31:728-740.

242. Parker JM, Oh CK, Laforce C, Miller SD, Pearlman DS, Le C, Robbie GJ, White WI, White B, Molfino NA: Safety profile and clinical activity of multiple subcutaneous doses of MEDI-528, a humanized anti-interleukin9 monoclonal antibody, in two randomized phase 2 a studies in subjects with asthma. BMC Pulm Med 2011, 11:14.

243. O'Garra A, Barrat FJ, Castro AG, Vicari A, Hawrylowicz C: Strategies for use of IL-10 or its antagonists in human disease. Immunol Rev 2008, 223:114-131.

244. Trinchieri G: Proinflammatory and immunoregulatory functions of interleukin-12. Int Rev Immunol 1998, 16:365-396.

245. Gavett SH, O'Hearn DJ, Li X, Huang SK, Finkelman FD, Wills-Karp M: Interleukin 12 inhibits antigen-induced airway hyperresponsiveness, inflammation, and Th2 cytokine expression in mice. J Exp Med 1995, 182:1527-1536.

246. Bryan SA, O'Connor BJ, Matti S, Leckie MJ, Kanabar V, Khan J, Warrington SJ, Renzetti $L$, Rames A, Bock JA, et al: Effects of recombinant human interleukin-12 on eosinophils, airway hyper-responsiveness, and the late asthmatic response. Lancet 2000, 356:2149-2153. 
247. Zhu Z, Homer RJ, Wang Z, Chen Q, Geba GP, Wang J, Zhang Y, Elias JA: Pulmonary expression of interleukin-13 causes inflammation, mucus hypersecretion, subepithelial fibrosis, physiologic abnormalities, and eotaxin production. J Clin Invest 1999, 103:779-788.

248. Brightling CE, Saha S, Hollins F: Interleukin-13: prospects for new treatments. Clin Exp Allergy:journal of the British Society for Allergy and Clinical Immunology 2010, 40:42-49.

249. Kasaian MT, Miller DK: IL-13 as a therapeutic target for respiratory disease. Biochem Pharmacol 2008, 76:147-155.

250. Ishimitsu R, Nishimura H, Yajima T, Watase T, Kawauchi H, Yoshikai Y: Overexpression of IL-15 in vivo enhances Tc1 response, which inhibits allergic inflammation in a murine model of asthma. J Immunol 2001, 166:1991-2001.

251. Hellings PW, Kasran A, Liu Z, Vandekerckhove P, Wuyts A, Overbergh L, Mathieu C, Ceuppens JL: Interleukin-17 orchestrates the granulocyte influx into airways after allergen inhalation in a mouse model of allergic asthma. Am J Respir Cell Mol Biol 2003, 28:42-50.

252. Schnyder-Candrian S, Togbe D, Couillin I, Mercier I, Brombacher F, Quesniaux V, Fossiez F, Ryffel B, Schnyder B: Interleukin-17 is a negative regulator of established allergic asthma. J Exp Med 2006, 203:2715-2725.

253. Nakanishi K, Yoshimoto T, Tsutsui H, Okamura H: Interleukin-18 regulates both Th1 and Th2 responses. Annu Rev Immunol 2001, 19:423-474.

254. Maecker HT, Hansen G, Walter DM, DeKruyff RH, Levy S, Umetsu DT: Vaccination with allergen-IL-18 fusion DNA protects against, and reverses established, airway hyperreactivity in a murine asthma model. $J$ Immunol 2001, 166:959-965.

255. Huang F, Wachi S, Thai P, Loukoianov A, Tan KH, Forteza RM, Wu R: Potentiation of IL-19 expression in airway epithelia by IL-17A and IL-4/ IL-13: important implications in asthma. J Allergy Clin Immunol 2008, 121:1415-1421.

256. Liao SC, Cheng YC, Wang YC, Wang CW, Yang SM, Yu CK, Shieh CC, Cheng KC, Lee MF, Chiang SR, et al: IL-19 induced Th2 cytokines and was up-regulated in asthma patients. J Immunol 2004, 173:6712-6718.

257. Sivakumar PV, Foster DC, Clegg CH: Interleukin-21 is a T-helper cytokine that regulates humoral immunity and cell-mediated anti-tumour responses. Immunology 2004, 112:177-182.

258. Besnard AG, Sabat R, Dumoutier L, Renauld JC, Willart M, Lambrecht B, Teixeira MM, Charron S, Fick L, Erard F, et al: Dual Role of IL-22 in allergic airway inflammation and its cross-talk with IL-17A. Am J Respir Crit Care Med 2011, 183:1153-1163.

259. Wakashin H, Hirose K, Maezawa Y, Kagami S, Suto A, Watanabe N, Saito Y, Hatano M, Tokuhisa T, Iwakura Y, et al: IL-23 and Th17 cells enhance Th2cell-mediated eosinophilic airway inflammation in mice. Am J Respir Crit Care Med 2008, 178:1023-1032.

260. Li Y, Sun M, Cheng H, Li S, Liu L, Qiao H, Hua S, Lu J: Silencing IL-23 expression by a small hairpin RNA protects against asthma in mice. Exp Mol Med 2011, 43:197-204.

261. Ballantyne SJ, Barlow JL, Jolin HE, Nath P, Williams AS, Chung KF, Sturton G, Wong SH, McKenzie AN: Blocking IL-25 prevents airway hyperresponsiveness in allergic asthma. J Allergy Clin Immunol 2007, 120:1324-1331.

262. Wang YH, Angkasekwinai P, Lu N, Voo KS, Arima K, Hanabuchi S, Hippe A, Corrigan CJ, Dong C, Homey B, et al: IL-25 augments type 2 immune responses by enhancing the expansion and functions of TSLP-DCactivated Th2 memory cells. J Exp Med 2007, 204:1837-1847.

263. Yoshimoto T, Yasuda K, Mizuguchi J, Nakanishi K: IL-27 suppresses Th2 cell development and Th2 cytokines production from polarized Th2 cells: a novel therapeutic way for Th2-mediated allergic inflammation. $J$ Immunol 2007, 179:4415-4423.

264. Dillon SR, Sprecher C, Hammond A, Bilsborough J, Rosenfeld-Franklin M, Presnell SR, Haugen HS, Maurer M, Harder B, Johnston J, et al: Interleukin 31 , a cytokine produced by activated $T$ cells, induces dermatitis in mice. Nat Immunol 2004, 5:752-760

265. Lei Z, Liu G, Huang Q, Lv M, Zu R, Zhang GM, Feng ZH, Huang B: SCF and IL-31 rather than IL-17 and BAFF are potential indicators in patients with allergic asthma. Allergy 2008, 63:327-332.

266. Lohning M, Stroehmann A, Coyle AJ, Grogan JL, Lin S, Gutierrez-Ramos JC, Levinson D, Radbruch A, Kamradt T: T1/ST2 is preferentially expressed on murine Th2 cells, independent of interleukin 4, interleukin 5, and interleukin 10, and important for Th2 effector function. Proc Natl Acad Sci USA 1998, 95:6930-6935.
267. Xu D, Chan WL, Leung BP, Huang F, Wheeler R, Piedrafita D, Robinson JH, Liew FY: Selective expression of a stable cell surface molecule on type 2 but not type 1 helper T cells. J Exp Med 1998, 187:787-794.

268. Schmitz J, Owyang A, Oldham E, Song Y, Murphy E, McClanahan TK, Zurawski G, Moshrefi M, Qin J, Li X, et al: IL-33, an interleukin-1-like cytokine that signals via the IL-1 receptor-related protein ST2 and induces T helper type 2-associated cytokines. Immunity 2005, 23:479-490.

269. Shannon J, Ernst P, Yamauchi Y, Olivenstein R, Lemiere C, Foley S, Cicora L, Ludwig M, Hamid Q, Martin JG: Differences in airway cytokine profile in severe asthma compared to moderate asthma. Chest 2008, 133:420-426.

270. Yang M, Kumar RK, Foster PS: Pathogenesis of steroid-resistant airway hyperresponsiveness: interaction between IFN-gamma and TLR4/MyD88 pathways. J Immunol 2009, 182:5107-5115.

271. Boguniewicz M, Schneider LC, Milgrom H, Newell D, Kelly N, Tam P, Izu AE, Jaffe HS, Bucalo LR, Leung DY: Treatment of steroid-dependent asthma with recombinant interferon-gamma. Clin Exp Allergy 1993, 23:785-790.

272. Gorelik L, Fields PE, Flavell RA: Cutting edge: TGF-beta inhibits Th type 2 development through inhibition of GATA-3 expression. J Immunol 2000, 165:4773-4777.

273. Fattouh R, Midence NG, Arias K, Johnson JR, Walker TD, Goncharova S, Souza KP, Gregory RC Jr, Lonning S, Gauldie J, Jordana M: Transforming growth factor-beta regulates house dust mite-induced allergic airway inflammation but not airway remodeling. Am J Respir Crit Care Med 2008, 177:593-603.

274. Alcorn JF, Rinaldi LM, Jaffe EF, van Loon M, Bates JH, Janssen-Heininger YM, Irvin CG: Transforming growth factor-beta1 suppresses airway hyperresponsiveness in allergic airway disease. Am J Respir Crit Care Med 2007, 176:974-982.

275. Brightling C, Berry M, Amrani Y: Targeting TNF-alpha: a novel therapeutic approach for asthma. J Allergy Clin Immunol 2008, 121:5-10, quiz 11-12.

276. Berry MA, Pavord ID: Antagonism of tumour necrosis factor alpha in refractory asthma. Thorax 2008, 63:571-572.

277. Wenzel SE, Barnes PJ, Bleecker ER, Bousquet J, Busse W, Dahlen SE, Holgate ST, Meyers DA, Rabe KF, Antczak A, et al: A randomized, doubleblind, placebo-controlled study of tumor necrosis factor-alpha blockade in severe persistent asthma. Am J Respir Crit Care Med 2009, 179:549-558.

doi:10.1186/1465-9921-12-114

Cite this article as: Bosnjak et al.: Treatment of allergic asthma:

Modulation of Th2 cells and their responses. Respiratory Research 2011 12:114.

\section{Submit your next manuscript to BioMed Central and take full advantage of:}

- Convenient online submission

- Thorough peer review

- No space constraints or color figure charges

- Immediate publication on acceptance

- Inclusion in PubMed, CAS, Scopus and Google Scholar

- Research which is freely available for redistribution 